REVITALIZATION OF A NATIVE WYOMING BIG SAGEBRUSH/BLUEBUNCH WHEATGRASS COMMUNITY IN CENTRAL IDAHO: A TEN YEAR SUMMARY
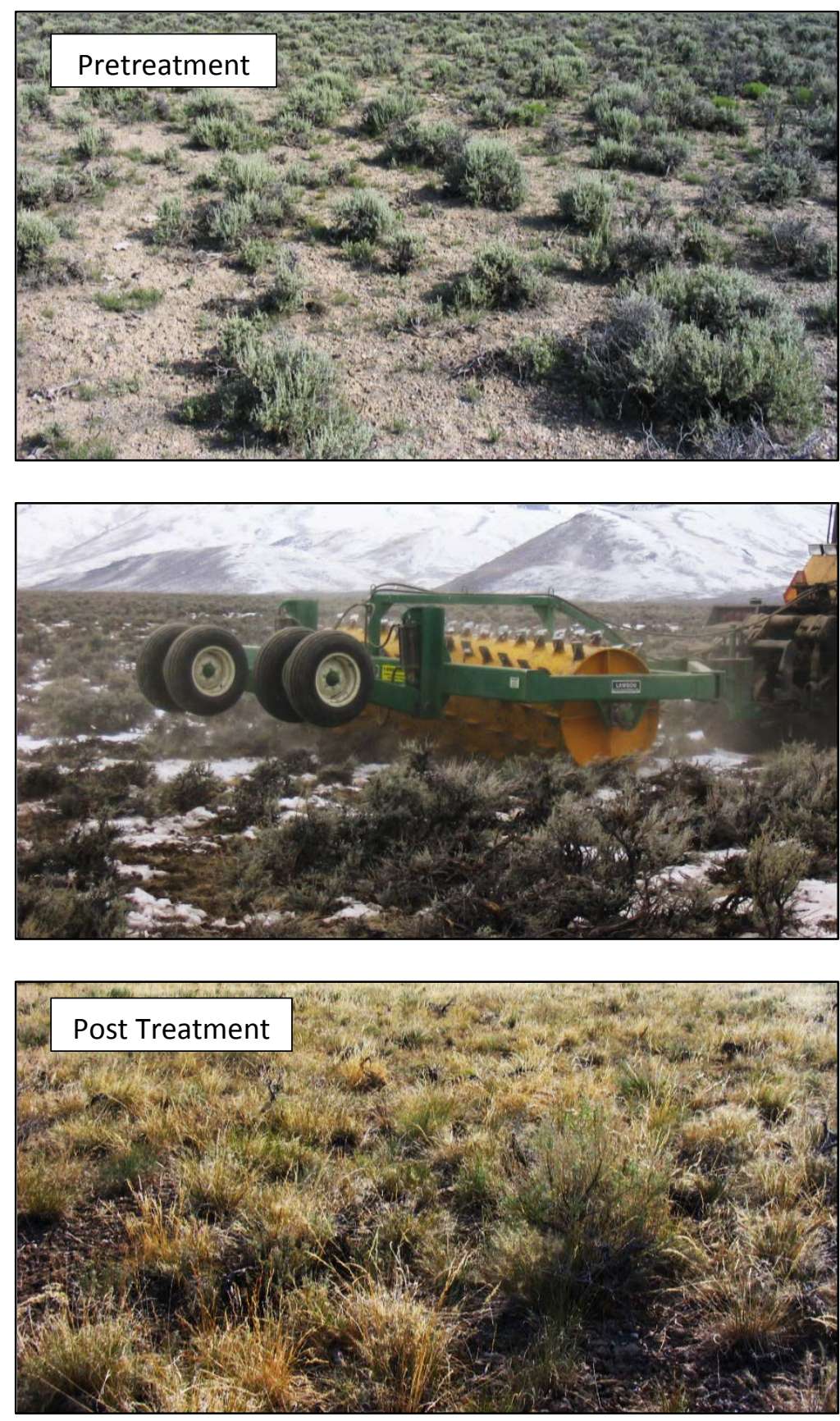

Jeffrey Yeo

December 2012

Bureau of Land Management Idaho Technical Bulletin 2014-01 


\title{
REVITALIZATION OF A NATIVE WYOMING BIG SAGEBRUSH/BLUEBUNCH WHEATGRASS COMMUNITY IN CENTRAL IDAHO: A TEN YEAR SUMMARY
}

\author{
Jeffrey J. Yeo, 518 N 350 E, SHOSHONE, IDAHO 83352 \\ SUMMARY
}

Sagebrush steppe communities with impoverished although mostly native herbaceous layers may represent the best of what's left of the sagebrush steppe ecosystem in North America. The other $75 \%$ of this ecosystem has been lost or substantially changed by the combined forces of development, agriculture, fire, and livestock grazing. Can we revitalize these impoverished communities effectively and what's causing these communities to remain static over decades? This project assessed several approaches for returning the vigor and productivity to a Wyoming big sagebrush/bluebunch wheatgrass community in central Idaho. I took an experimental approach to assess restoration techniques. The project occurred on a single mapped soil unit within a single pasture of the Bureau of Land Management's Upper Pahsimeroi grazing allotment. Sample units all occurred on generally flat sites (slope $=0-5 \%)$ and similar elevations (2010 - $2075 \mathrm{~m}$ [6595-6810 ft]). Fifteen 4-ha (10 ac) sample units were positioned randomly within the project area prior to treatments being applied, and treatments (controls, mechanical crushing only, and mechanical crushing with seeding of native grasses) were assigned randomly to sample units. Half the area of each sample unit was fenced to exclude livestock. Each treatment was replicated 5 times. The total area encompassed by the sample units was 150 ha with 30 ha treated with mechanical crushing. Mechanical crushing of sagebrush and other shrubs was accomplished by 2 passes of a Lawson aerator over each treatment area during November 2003 after snow had fallen. A rangeland drill was used to seed a mixture of $90 \%$ bluebunch wheatgrass and $10 \%$ Indian ricegrass (at a rate of $11-13 \mathrm{~kg} / \mathrm{ha}$ [10-12 lbs/ac]) immediately after crushing was completed. Sampling occurred in the year prior to application of treatments (2003) and in 3 subsequent years following treatment $-2005,2007$, and 2012 . Cover of plants, exposed soil, biological crust, and litter was the response metric for assessing treatment effects. Cover was estimated using 10 pointinterception transects in each treatment combination. Cover of Wyoming big sagebrush on control sites, both open to livestock grazing and closed, increased slightly (from 17-19\% in 2003 to $23-25 \%$ in 2012). Mechanical crushing reduced Wyoming big sagebrush cover 63\%from an average of $19 \%$ in 2003 (range: $11-32 \%$ ) to an average of 7\% in 2005 (range: 2-12\%). By 2012, 9 growing seasons post-treatment, average big sagebrush cover had increased to $11 \%$ (range: 1-20\%); an increase from 2005 of $42 \%$. Crushing \& seeding resulted in substantial increases in bluebunch wheatgrass cover from about 1-2\% cover in 2003 to an average of $33 \%$ in 2012. The reduction in competition from sagebrush apparently resulted in increases in squirreltail cover (particularly in areas open to livestock grazing) and increases in needle and thread cover (particularly in areas protected from livestock grazing). The cover of exposed soil in areas treated with crushing fell below pretreatment levels on most treatments (except controls open to livestock grazing) with increased vegetative cover. Biological crusts suffered limited impact from crushing and increased cover with protection from livestock grazing. My recommendations for using a mechanical crushing and seeding approach for range improvement in depauperate Wyoming big sagebrush/bluebunch wheatgrass communities include the following: (1) provide a period of nonuse of 4-5 years following crushing \& seeding as other authors have recommended and even longer if special circumstances occur such as drought,(2) institute conservative livestock management for the first 10 years or so that prioritizes recovery and establishment of vigorous native plant communities in treated areas (e.g. light grazing in mid to late summer following seed set of bluebunch wheatgrass), and (3) in areas where cheatgrass invasion is a concern, managers should consider not implementing this restoration approach unless other methods are available for controlling cheatgrass. 


\section{INTRODUCTION}

The seemingly vast sagebrush steppe of the American west has been altered substantially (an estimated $75 \%$ of the ecosystem) as a result of conversion to agriculture or other development, fire and subsequent dominance by non-native annual grasses, and historic overgrazing by livestock (Noss et al. 1995, Hann et al. 1997, West 2000). The remaining $25 \%$ of the ecosystem may still harbor mostly native species but the herbaceous species are much less productive and diverse than are considered to be the pristine condition (West 2000). Revitalization of this native but depauperate remnant of sagebrush steppe may be more readily and quickly achieved than attempting to restore the larger portion that has been changed or lost. Revitalization may provide needed boosts to many faltering populations of sagebrush obligate wildlife such as the greater sage-grouse (Centrocercus urophasianus) and passerine birds that have experienced widespread declines in recent decades (Paige and Ritter 1999, Connelly et al. 2000, Sands et al. 2000).

Large portions of sagebrush steppe within the Bureau of Land Management Challis Field Office (Challis FO) management area support these impoverished but mostly native communities particularly in the more arid Wyoming big sagebrush (Artemisia tridentata wyomingensis) communities at the lower elevations (J. Yeo, personal observation). Bluebunch wheatgrass (Pseudoroegneria spicata) is the expected co-dominant plant species in these communities but typically contributes little canopy cover $(<$ 1-2\%); instead the stands are typified by substantial areas of exposed soil between individual sagebrush plants with Sandberg bluegrass (Poa secunda) and ground-hugging forbs providing scant cover. My presumption was that $>100$ years of livestock grazing (cattle and sheep) combined with low annual precipitation and competition from sagebrush and Sandberg bluegrass had severely reduced bluebunch wheatgrass and forbs. Stand succession appeared stagnant (J. Yeo, personal observation). This condition may continue for decades even with the reduction or removal of livestock grazing (West et al. 1984, West 2000).

Three primary disturbances influenced these arid sagebrush steppe ecosystems during the past century and more: drought, fire, and livestock grazing. Native sagebrush steppe species are adapted to natural disturbances, and disturbance can be induced by managers to achieve desired conditions. To revitalize these communities then may require a reduction of livestock grazing pressure (or livestock removal) and substantial community disturbance (possible combined with seeding) to reset interspecific plant dynamics. Livestock removal alone may not result in appreciable community change for several decades because of the arid conditions and a paucity of native seed on-site for plants with low cover (Anderson and Inouye 2001, Valone 2001, Yeo 2005). Significant disturbance may be necessary to change the depleted condition and liberate resources to allow expansion of suppressed species (e.g., bluebunch wheatgrass and forbs).

Yet, there is uncertainty in the outcomes of disturbances, and the consequences can be negative (Eddleman and Doescher 2000). Recovery of sagebrush after fire to pre-disturbance cover values can take many decades (Bunting et al. 1987). Exotic annuals, e.g. cheatgrass (Bromus tectorum), can invade following disturbances and permanently change fire frequencies and community dynamics (Pyke 2000). Fire, livestock trampling, and crushing by vehicles can destroy biotic soil crusts (Belnap 2000). Therefore, caution in introducing disturbance as a management tool is warranted and rangeland restoration designed as experiments can inform management in an adaptive approach.

This project assessed the use of mechanical crushing of shrubs as an alternative to prescribed fire to stimulate revitalization of cover and vigor of bluebunch wheatgrass and other native herbs. The project was designed to address several questions about community responses to range restoration including: 
- Does mechanical brush crushing, which is expected to mostly impact mature shrubs, retain sufficient young age sagebrush and seedlings to allow more rapid recovery of sagebrush cover than expected from prescribed fire treatment?

- Does bluebunch wheatgrass cover (and the herb understory) increase in response to the reduction of sagebrush and other shrubs as a result of mechanical crushing?

- Do bluebunch wheatgrass and other herb cover increase with the removal of livestock grazing?

This report details vegetation response spanning the first 9 growing seasons following treatment with mechanical crushing. 


\section{METHODS}

\section{Project Area}

The project was located in the Pahsimeroi Valley of east-central Idaho within the Challis FO Upper Pahsimeroi grazing allotment. The project area encompassed 2000 ha situated within a broad, flat valley (elevation range $=2010-2075 \mathrm{~m}[6595-6810 \mathrm{ft}]$ and slopes $0-5 \%$ ), and underlain by a single mapped soil type within a single pasture of the allotment. The soils are gravelly loams with expected annual precipitation of 205-308 mm (8-12 in; Natural Resources Conservation Service 2002). Bluebunch wheatgrass is expected to dominate productivity ( $40 \%$ by weight) with Wyoming big sagebrush contributing 20\%. Sandberg bluegrass, Indian ricegrass (Achnatherum hymenoides), needle and thread (Hesperostipa comata) each may contribute $5 \%$ to the composition. Other perennial grasses, such as squirreltail (Elymus elymoides), may contribute as much as $10 \%$. Spiny phlox (Phlox hoodii) is expected to contribute $5 \%$ and other perennial forbs an additional $5 \%$. Going back many years before the initiation of this project, plant community composition did not reflect this expectation. An open stand of Wyoming big sagebrush ( $20 \%$ cover) with a sparse, species-poor understory of Sandberg bluegrass ( $12-14 \%$ cover), total forb cover only 3\%, and about $20-30 \%$ bare ground cover prevailed even in very wet years such as 1998 (J. Yeo, personal observation). Bluebunch wheatgrass contributed about 1\% cover. Non-native plants, such as cheatgrass, were rare in the project area.

Cattle were grazed within the allotment in a deferred rotation grazing system. Vegetation was sampled in 2003, 2005, and 2007 during the first week of July, and in late June in 2012. During 2003 and 2005, cattle entered the pasture encompassing the project (West Flat pasture) in early July about the same time that sampling was conducted so that grazing had little impact on measures of cover in those years. In 2007, cattle entered the pasture in mid-June resulting in about 2 weeks of grazing prior to vegetation sampling. In 2012, cattle were kept from the project area until the beginning of July to allow data collection to be completed before grazing occurred. Livestock use (indexed by animal unit months, AUMs) has fluctuated during the period of study with the earliest grazing (other than simply trailing through the pasture) occurring in 2007 (Table 1). AUMs were highest in 2009 (Figure 1).

\section{Weather}

An automated weather station was placed in the center of the project area in early April 2003. The station recorded ambient temperature $(C)$, rainfall $(\mathrm{mm})$, solar radiation $\left(\mathrm{w} / \mathrm{m}^{2}\right)$, wind speed $(\mathrm{kph})$, wind direction (degrees), relative humidity (\%), soil temperature (C) at $25 \mathrm{~cm}$ (10 in) rooting depth, and soil moisture (centibars) at two rooting depths: $25 \mathrm{~cm}$ and $75 \mathrm{~cm}$ (30 in). Additionally, evapotranspiration was calculated. Measurements were taken every minute and integrated on an hourly basis with data saved to a data logger.

Weather data were recorded from April 2003 through June 2012. There were 23 months over this period that had missing records. These gaps resulted from inability to download data during winter months and problems with maintaining power to the data logger. The nearest National Weather Service station is located in the Pahsimeroi Valley at May, Idaho, about $35 \mathrm{~km}$ (22 miles) northeast of the project area (station no. 105685). The elevation at the May station is $1560 \mathrm{~m}(5120 \mathrm{ft}$ ) while elevation at the project weather station is $2042 \mathrm{~m}$ (7000 ft). Precipitation and temperature data collected at May, Idaho were compared with data from the project weather station. Monthly precipitation at May was significantly correlated with precipitation at the project weather station $(r=0.82, P<0.001, \mathrm{n}=88$ months). Likewise, average monthly temperatures were highly correlated between the two weather stations ( $r=0.98, P<0.001, \mathrm{n}=87$ months). Therefore, I used the May weather record to depict 
weather patterns for the project area. Comparison of the 2 weather station records indicate that the project area was generally drier and cooler than at May with 1 notable exception - in June 2009, the project weather station recorded $124 \mathrm{~mm}$ (4.9 in) of rainfall while at the May weather station $87 \mathrm{~mm}$ (3.4 in) of rainfall was recorded.

Climate diagrams (Walter et al. 1975) are useful for depicting average climate conditions for an area and the pattern of dry and moist periods throughout the course of a year. Annual climate diagrams for the May weather station from 2001 through summer 2012 describe changes in the availability of water for plant growth (Figure 2). The years 2004 and 2005 had robust peaks of rainfall during the spring, and 2005 and 2006 had comparatively short dry periods indicating that plant growth conditions were more favorable than in the previous $2001-2003$ period. Long and severe dry periods also were evident in 2007 and 2008 with very limited rainfall prior to summer. Abnormally high levels of spring precipitation were experienced in 2009 and 2010, and the period 2009 through 2012 would appear to be very favorable for plant growth. So, $2001-2003$, and $2007-2008$ were poor years for plant growth. The years $2004-2006$, and $2009-2012$ were moister and likely much more favorable for plant growth.

\section{Treatments}

I conducted an a priori power analysis to determine the number of treatment replications needed to achieve a power $=0.80$ at $\alpha=0.05$ with paired comparisons. Restoration of a vigorous understory of bluebunch wheatgrass was the principal objective of the project so I used data on cover of bluebunch wheatgrass collected during June 2002 as part of a sagebrush avian research project to provide an estimate of median cover values for the Challis FO area. I compared average bluebunch wheatgrass cover collected from within the restoration project area (cover $=1.8 \% \pm 2.2 \%$ ) to the median value of bluebunch wheatgrass cover from 13 other stands of Wyoming big sagebrush/bluebunch wheatgrass vegetation within the Challis Field Office area (cover $=13.4 \% \pm 5.3 \%$ ). I calculated the standard deviation of the differences between treatments (based on the sample variances and an assumption of high correlation of response $[r=0.80]$ ) as 4.61 . This produced a sample size estimation of 4 replications/treatment. I varied the standard deviation of the differences up to $6 \%$ to allow for greater variances, which resulted in 5 treatment replications as sufficient.

The experimental units were located within the project area using a systematic random sampling design with two restrictions: all sites were $>0.4 \mathrm{~km}$ from water troughs to avoid areas of excessive livestock use, and plots didn't straddle established roads including two-tracks. This approach provided random placement of each unit with good dispersion of units throughout the project area. Each unit was oriented along the axes of the UTM grid, which are approximately 2 degrees west of true north and 2 degrees south of true west (based on 1989 USGS quad). The corners of each 2-ha paired plot were identified using a global positioning system (GPS).

One of 3 treatments were employed on 15 experimental units: (1) mechanical brush crushing augmented by seeding with native grasses using a rangeland drill ("crushed \& seeded"), (2) mechanical brush crushing with natural seeding by resident plants ("crushed only"), and (3) no treatment ("control"). In November 2003, ten of these sites were treated with mechanical brush crushing (using 2 passes in opposite directions over each treated area with an empty Lawson pasture aerator) in 2 parallel 30-m wide strips (with a $30 \mathrm{~m}$ strip in between - see Figure 3 ) in an effort to stimulate productivity of native grasses and forbs. Each experimental unit was 4 ha with half ( 2 ha) fenced to exclude livestock (yet permit access by wildlife, "closed" site), and the other half left open to livestock grazing ("open" site). The half of each unit to be fenced was chosen randomly. Within treated sites, there were areas where the treatment occurred and adjacent areas where no treatment occurred. I included these 
adjacent untreated areas as separate treatments to evaluate whether areas adjacent to treated areas might also show increased herbaceous cover as a result of increased seed sources in the treated areas (Figure 4).

Experimental units were sampled in early July 2003 prior to treatment and fencing. Bluebunch wheatgrass and Indian ricegrass were seeded on 5 of the treated units using a rangeland drill immediately after mechanical crushing. The depth of the drill settings were variable, approximately $2.5-$ $5 \mathrm{~cm}$ (1-2 in) (L. Redick, BLM, personal communication), which was intended to accommodate the differences in recommended seeding depths for bluebunch wheatgrass $(0.3-0.6 \mathrm{~cm})$ and Indian ricegrass (> $2 \mathrm{~cm}$ ) (Monsen et al. 2004, Lambert 2005). The seed mix was $90 \%$ bluebunch wheatgrass (Goldar variety) and $10 \%$ Indian ricegrass (NezPar variety) at a rate of $11-13 \mathrm{~kg} / \mathrm{ha}(10-12 \mathrm{lbs} / \mathrm{ac}$ ). Fencing of the grazing exclosures was completed in spring of 2004. Treated areas that were intended to be open to livestock grazing were enclosed by a temporary electric fence for 1 year to protect these sites from grazing for the first year post-treatment. Subsequent sampling occurred in early July of 2005 and 2007, and late June of 2012.

\section{Vegetation Cover}

Vegetation cover and ground cover were estimated within each 2-ha experimental site on 10 randomlylocated, permanent transects (15 interception points/transect). Transects were perpendicular to the long central axis of each unit with 6 transects ( $n=90$ interception points) positioned within the $230-\mathrm{m}$ wide treatment strips and 4 transects ( $n=60$ interception points) positioned in adjacent untreated areas (Figures $3 \& 4$ ). Each point was considered independent with 2-m distance (3 strides) between points so that the transects served to provide good dispersion of points throughout the unit while allowing greater sampling efficiency. The positioning and length of the transects provided $\mathrm{a} \geq 15 \mathrm{~m}$ buffer where no sampling occurred between the grazing exclosure fences and sample points to avoid concentrated trampling from cattle trailing along fence lines.

Point interceptions along each transect (using a leveled laser pointer device) were used to estimate canopy cover of vegetation, and cover of exposed soil (defined as soils not overlain by a canopy or covered by vegetation, rock, and litter; Society of Range Management 1999), and biological crust. Canopy cover was defined as "the percentage of the ground covered by a vertical projection of the outermost perimeter of the natural spread of foliage of plants" (Society of Range Management 1999). Biological crusts were defined as cryptogams - lichens and mosses including vagrant lichens - that were readily observed on the soil surface. Plant names follow the Natural Resources Conservation Service (NRCS) plants database (plants.usda.gov) naming conventions.

\section{Data Analyses}

The Pearson correlation index was used to compare May weather station data to the project weather station records. Cover estimates for principal variables for each unit are summarized in tabular form in Appendix A. Bar graphs for the principal variables showing mean cover values and $95 \%$ confidence intervals are used to compare among treatments in open and closed units. Paired t-tests also were used to compare between treatments or between years. Data were tested for normality prior to using t-tests. Estimates were deemed significantly different at $\alpha=0.05$. Although cover of standing dead sagebrush, litter, and surface rock was included in cover estimates these data are not presented because I didn't think they provided additional insights about community response to mechanical crushing. 
Table 1. Cattle numbers, animal unit months (AUMs), and beginning and end dates of livestock grazing for the West Flat Pasture, Upper Pahsimeroi Allotment. The West Flat Pasture is 4961 ha $(12,260 \mathrm{ac})$.

\begin{tabular}{|c|c|c|c|c|c|}
\hline Year & $\begin{array}{l}\text { Cattle } \\
\text { Numbers }\end{array}$ & $\begin{array}{l}\text { Begin } \\
\text { Date }\end{array}$ & $\begin{array}{l}\text { End } \\
\text { Date }\end{array}$ & AUMs & Comments \\
\hline \multirow[t]{2}{*}{2003} & 350 & 1-Jul & 1-Aug & 368 & \\
\hline & 550 & 1-Aug & 14-Aug & 253 & \\
\hline \multirow[t]{2}{*}{2004} & 350 & 1-Jul & 1-Aug & 368 & \\
\hline & 550 & 2-Aug & 14-Aug & 235 & \\
\hline \multirow[t]{2}{*}{2005} & 250 & 1-Jul & 1-Aug & 263 & \\
\hline & 550 & 2-Aug & 14-Aug & 235 & \\
\hline 2006 & 349 & 6-Jul & 21-Aug & 539 & \\
\hline \multirow[t]{3}{*}{2007} & 531 & 14-Jun & 2-Aug & 600 & \\
\hline & & 3-Aug & 4-Aug & 35 & gathering/trailing \\
\hline & & 6-Sep & 6-Sep & 17 & trailing \\
\hline 2008 & 450 & 30-Jun & 8-Aug & 395 & \\
\hline 2009 & 522 & 21-Jun & 8-Aug & 841 & \\
\hline \multirow[t]{2}{*}{2010} & 585 & 30-Jun & 9-Jul & 63 & gathering/trailing \\
\hline & 578 & 10-Jul & 2-Sep & 448 & \\
\hline \multirow[t]{3}{*}{2011} & 550 & 11-Jun & 15-Jun & 66 & trailing \\
\hline & 550 & 1-Jul & 29-Aug & 601 & \\
\hline & 534 & 5-Sep & 6-Sep & 35 & trailing \\
\hline
\end{tabular}

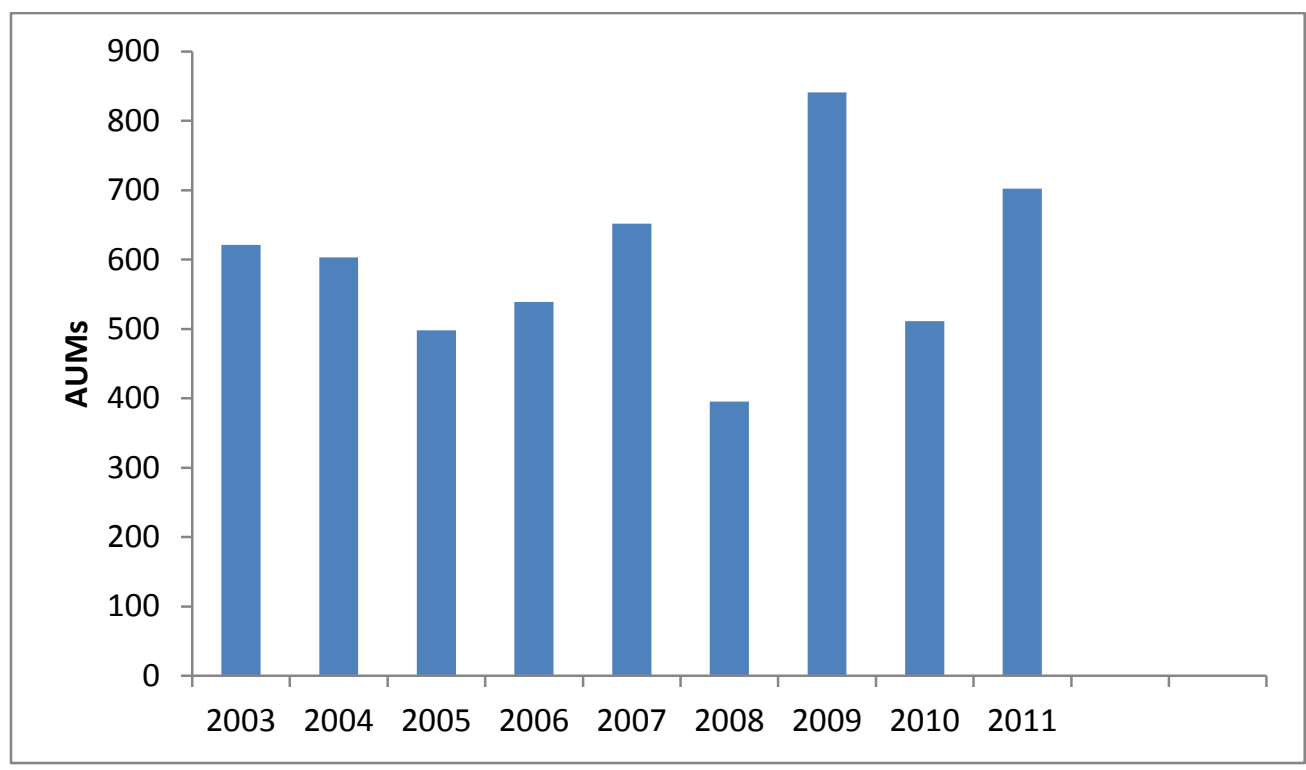

Figure 1. Change in livestock grazing AUMs for the West Flat Pasture, Upper Pahsimeroi Allotment, 2003-2011. 


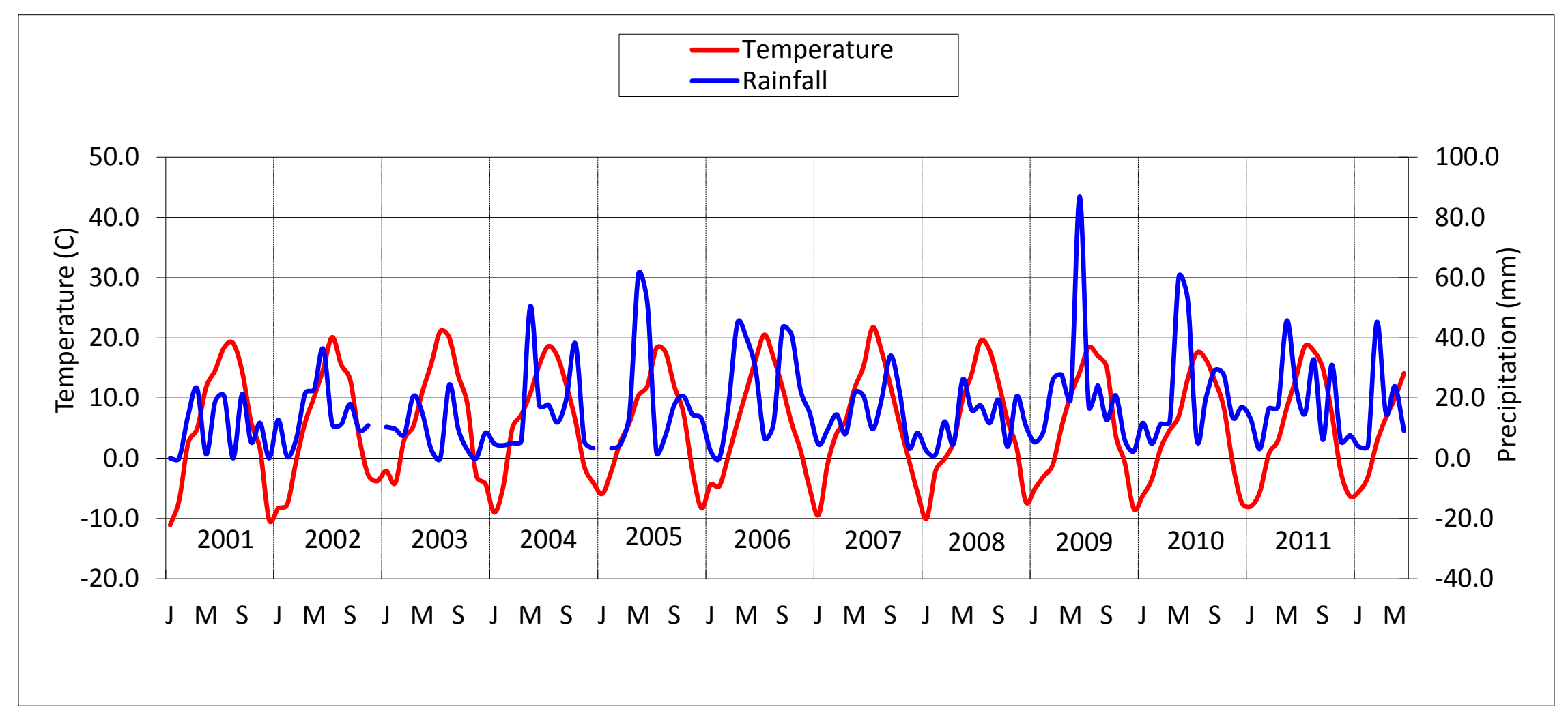

Figure 2. Continuous climate diagram (Walter et al. 1975) for the May, Idaho weather station from 2001 through June 2012. Periods when temperature exceeds precipitation are arid. Extended dry periods are evident in 2001, 2003, 2007, and 2008. Moister springs are evident for 2004, 2005, and particularly in 2009, 2010, and 2012. J = January, M = May, S= September. 


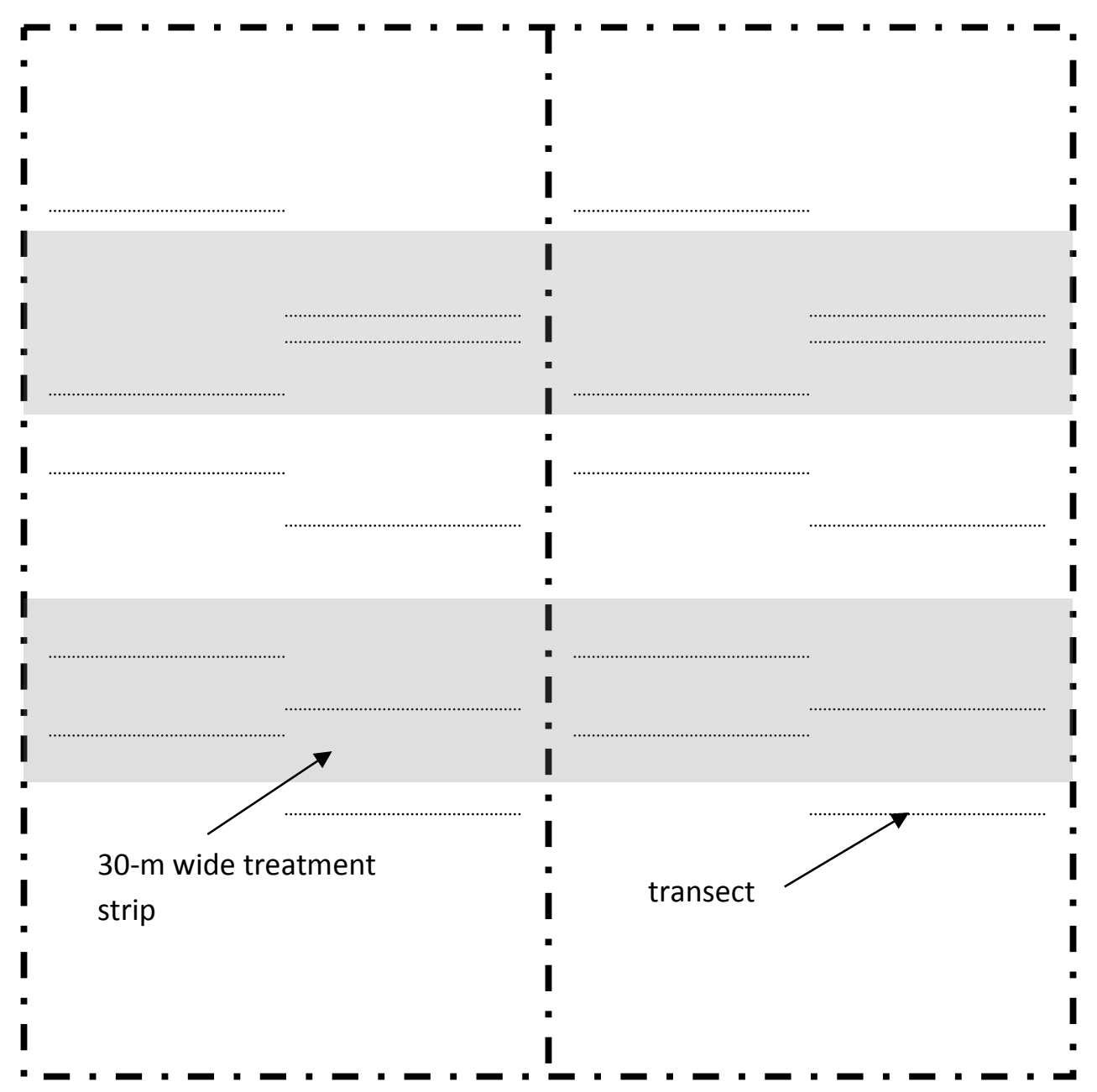

Figure 3. Transect distribution within experimental units. Shaded strips are areas treated with the Lawson aerator in fall 2003. Transects were randomly located prior to initial sampling in 2003. One half of the unit was fenced to exclude livestock, the other half left open to livestock grazing (although this side was fenced with temporary electric fencing to exclude livestock for 1 year after treatment to allow establishment per BLM policy). 


\begin{tabular}{|c|c|c|}
\hline Experimental Unit & Grazing & Mechanical Crushing \\
\hline \multirow{2}{*}{ Control } & Closed & \multirow{2}{*}{ Untreated } \\
\hline & Open & \\
\hline \multirow{4}{*}{ Crushed Only } & \multirow{2}{*}{ Closed } & Treated \\
\hline & & Untreated \\
\hline & \multirow{2}{*}{ Open } & Treated \\
\hline & & Untreated \\
\hline \multirow{4}{*}{ Crushed \& Seeded } & \multirow{2}{*}{ Closed } & Treated \\
\hline & & Untreated \\
\hline & \multirow{2}{*}{ Open } & Treated \\
\hline & & Untreated \\
\hline
\end{tabular}

Figure 4. Experimental treatments with each treatment combination replicated at 5 sites. 


\section{RESULTS}

\section{Sagebrush}

Wyoming big sagebrush cover averaged 17\% in 2003 across all experimental sites (range: $10-28 \%$ cover). On control sites, sagebrush cover remained similar on both closed and open sites with some apparent increase in average cover between 2003 and 2012 (Figure 5). Crushing with the aerator reduced sagebrush cover (60-73\%) to 6-8\% average cover by 2005 regardless of the amount of cover prior to the treatment. By 2012, on crushed sites, average sagebrush cover had increased to about $10 \%$ (range: 9-16\%). This was less than half of the cover on control sites. Comparison between crushed areas and adjacent uncrushed areas indicates that sagebrush cover on crushed sites was significantly less than the cover of adjacent uncrushed sites in $2012(P<0.05)$. However, on crushed only sites open to livestock grazing, sagebrush cover averaged $16 \%$ in 2012 ; still significantly less than the $25 \%$ average sagebrush cover on adjacent, uncrushed areas.

Sagebrush cover response was variable among sites. At 3 sites, Wyoming big sagebrush declined following crushing from $7 \%$ to $\leq 4 \%$ estimated cover (Appendix A.1). Four sites that were crushed only (not seeded) had cover $\geq 15 \%$ in 2012 .

\section{Grasses}

Bluebunch Wheatgrass - In 2003, cover estimates for bluebunch wheatgrass, prior to project fencing of grazing exclosures and treatments, were similar among the experimental sites; $\bar{x}$ cover averaged $1 \%$ (range: $0-6 \%$ ). By 2012, average cover had increased within closed sites to $12-13 \%$ at control and crushed only sites (Figure 6). Cover at closed, seeded sites in 2012 had increased to an average of 33\%, significantly greater than the other 2 treatments $(P<0.05)$. There was substantial variability among sites in cover response with 11 of 30 treatment sites (control, crushed only, crushed \& seeded for both open or closed areas) demonstrating no obvious directional response or change (Appendix A.2).

A pattern of higher average cover of wheatgrass in closed sites compared to adjacent open sites emerged over the period of study. Cover estimates for wheatgrass were substantially greater within closed, crushed \& seeded sites than open, crushed \& seeded sites in 2007 ( $P=0.045 ; \bar{x}$ difference $=15 \%$ cover), and in 2012 ( $P=0.013 ; \bar{x}$ difference $=21 \%)$. Seeding and leaving open to livestock grazing resulted in cover values similar to removing livestock with no treatment ( $12 \%$ and $13 \%$, respectively; Appendix A.2).

Sandberg Bluegrass - Sandberg bluegrass had the highest cover of all grasses across all sites prior to the initiation of the project ( $\bar{x}=13 \%$; range: $11-14 \%)$. Cover increased both on open sites and closed sites between 2003 and 2012 although the increase was greater on open sites from 2007 on (Figure 7). In 2007 (a very dry growing season), there was a pronounced increase in bluegrass cover for all treatments. This increase continued on sites open to livestock grazing in 2012. In 2012, at control sites and crushed \& seeded sites, Sandberg bluegrass cover was significantly greater on areas open to livestock grazing compared to adjacent areas closed to livestock $(P<0.05)$. On crushed \& seeded sites within grazing exclosures, bluegrass cover declined noticeably in 2012 and was significantly less than cover values in exclosures for controls and crushed only sites $(P<0.05)$. Cover was $11 \%$ greater on open sites than closed sites at controls in $2012(P<0.001)$. Bluegrass cover was $20 \%$ greater on open sites than closed sites for crushed \& seeded sites $(P=0.004)$. Crushed only sites had similar bluegrass cover values in 2012 between closed and open areas $(P=0.13)$. 
However, not all sites responded as portrayed by average values. Seven of 30 sites had similar cover values between 2003 and 2012 although there were fluctuations among years (Appendix A.3).

Comparison between cover values of bluebunch wheatgrass and Sandberg bluegrass within exclosures for all 3 treatments showed a significant negative correlation, i.e. where wheatgrass cover was high, bluegrass cover was low $(r=-0.76, P=0.001 \mathrm{n}=15)$. There was not a similar significant correlation on sites open to livestock grazing $(r=-0.32, P=0.24, \mathrm{n}=15)$.

Squirreltail - Squirreltail averaged slightly greater cover than bluebunch wheatgrass in 2003 ( $\bar{x}=4 \%$; range: 3-6\%; Appendix A.4). Cover estimates increased substantially in 2005 and 2007; more so on sites that had been crushed (Figure 8). There appeared to be some reduction in cover on crushed \& seeded sites by 2012. Considerable variability was evident among sites - by 2012 nine of 30 sites reverted to cover values similar to 2003 after increases in 2005 and 2007 (Appendix A.4). Squirreltail averaged higher cover on crushed areas than adjacent uncrushed areas within grazing exclosures in 2007 and $2012(P<0.05)$.

Needle and Thread - Needle and thread generally had low cover in 2003 similar to squirreltail $(\bar{x}=4 \%$, range: 3-6\%). Cover increased in subsequent years more so on sites closed to grazing (Figure 9). Higher cover values were more common on closed, crushed only sites (but only on 3 of 5 sites; Appendix A.5). Some sites maintained low cover values from 2003 to 2012 (Units 8, 7, 12, and 14 \& 15 on open areas). Average cover was greater on closed sites than on open sites in 2012 for controls and crushed \& seeded sites $(P<0.05)$.

Indian Ricegrass - Although Indian ricegrass comprised $10 \%$ of the seed mixture (i.e. $1.1-1.3 \mathrm{~kg} / \mathrm{ha}$ ), it was encountered rarely at any site in any year. On crushed \& seeded sites in 2012, ricegrass contributed $<1 \%$ cover on average (no cover recorded on 3 of the 5 crushed $\&$ seeded sites).

Cheatgrass - In 2003, cheatgrass occurred sparsely along the main road corridor that runs north-south through the project area. I encountered 1 cheatgrass plant at 1 point in 2007 across all the units. I again encountered 1 plant at 1 point in 2012. However, while visiting a few of the exclosures in 2010, I observed a small, dense patch of cheatgrass within the exclosure of 1 site. This patch was near the end of the treated area and elk sign was prevalent. In 2012, I observed 3 dense patches of cheatgrass on areas apparently disturbed by ground squirrels within the closed side of site 14 , a crushed \& seeded treatment. All 3 patches were within the northern treatment strip of the exclosure. Elk sign (pellets, tracks) were abundant. Patches were $\sim 2 \mathrm{~m}$ in diameter. I only encountered 1 cheatgrass plant along transects in this exclosure.

\section{Forbs}

Forb cover changed little over the course of the project regardless of treatment although there was variation among years and among sites (Figure 10). The closed side of Unit 10 consistently had greater forb cover than other sites (Appendix A.6). In general, forb cover was $\leq 5 \%$. Spiny phlox and stemless mock goldenweed (Stenotus acaulis) were the most consistently prevalent forbs across the years of study. Other forbs such as daisies (Erigeron spp.) and Indian paintbrush (Castilleja spp.) occasionally had cover values similar to phlox and goldenweed on some sites.

\section{Ground Cover}

Exposed Soil - Cover of exposed soil declined on sites closed to livestock grazing, even on sites treated with crushing (Figure 11). On control sites open to livestock grazing, cover of exposed soil remained similar across the period of study (except for site 8 which had increased exposed soil in 2012 which may 
have resulted from livestock trailing prior to sampling along the central roadway which runs adjacent to site 8; Appendix A.7). Within adjacent exclosures, cover became significantly less by 2007 and continued less in $2012(P<0.05)$. Mechanical crushing didn't result in more exposed soil cover within 2 years after treatment. On areas open to livestock grazing, crushed only treatments and crushed \& seeded treatments had significantly less cover of exposed soil than on control sites as a result of higher cover of litter (litter data not shown).

Biological Crust - Cover of biological crust changed little on sites open to livestock grazing from 2003 to 2012 regardless of treatment (Figure 12). Within grazing exclosures, crust cover increased over the project period on most sites, and was greater than on open sites for any treatment $(P<0.05)$. There was $\sim 6 \%$ greater cover of crust on closed sites versus open sites for controls in $2012(P=0.005)$. Twelve of 15 open sites had similar cover values in 2003 and 2012 while 3 of 15 closed sites also showed little change in crust cover over the project period (Appendix A.8). 

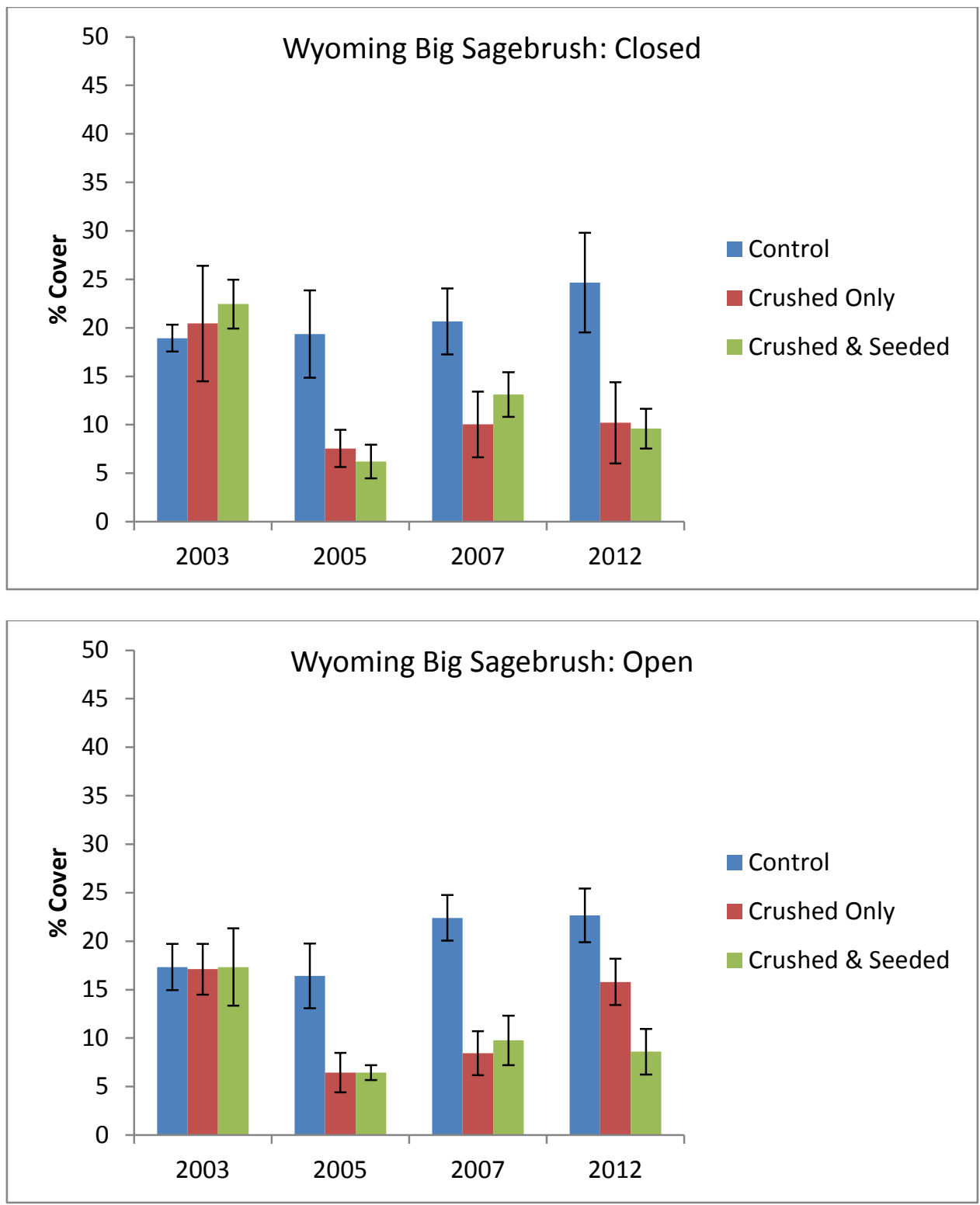

Figure 5. Response of Wyoming big sagebrush cover to 3 treatments closed and open to livestock grazing. Bars represent mean \% cover values ( $n=5$ sites) and error bars represent $95 \%$ confidence intervals. 

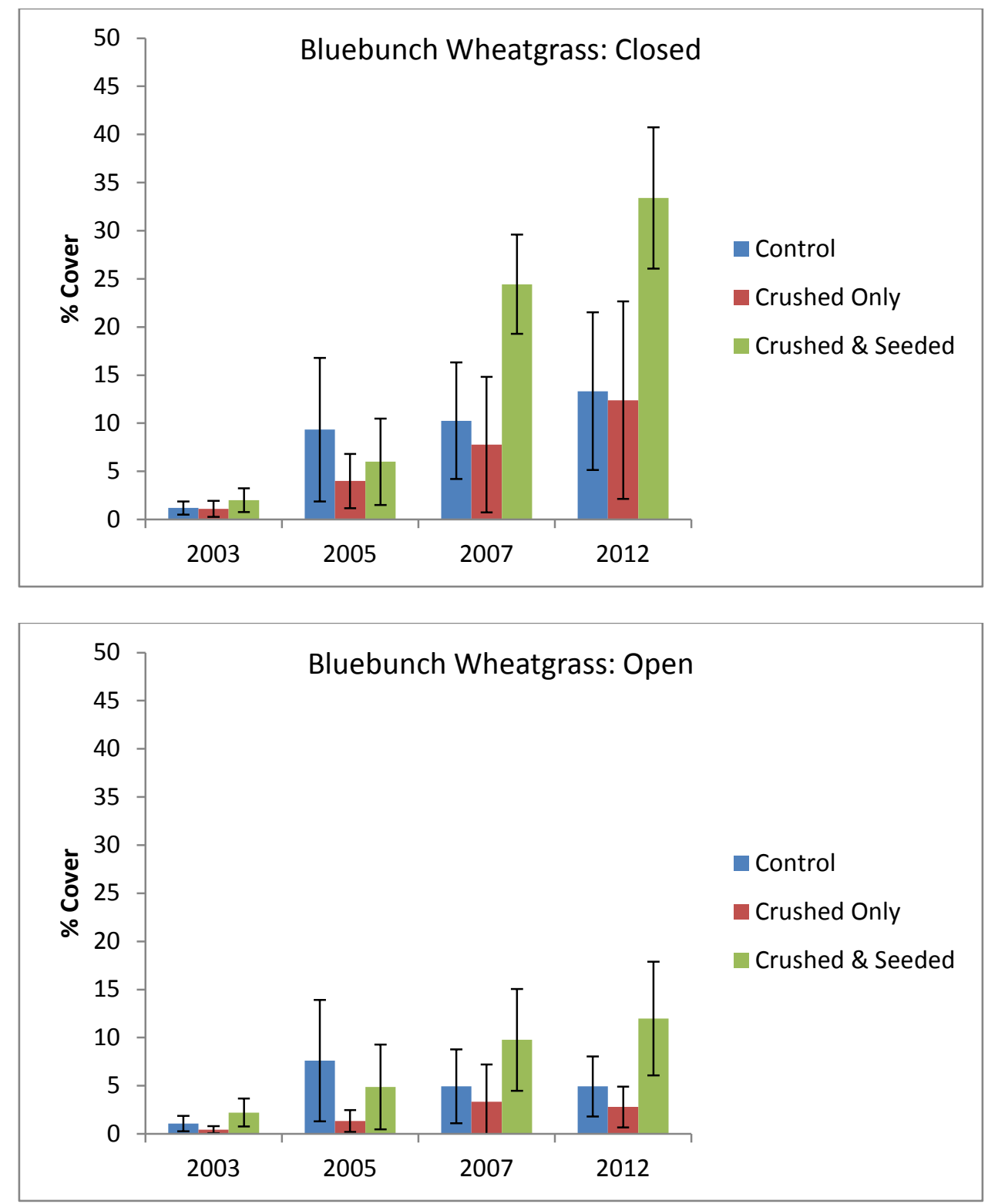

Figure 6. Response of bluebunch wheatgrass cover to 3 treatments closed and open to livestock grazing. Bars represent mean \% cover values ( $n=5$ sites) and error bars represent $95 \%$ confidence intervals. 

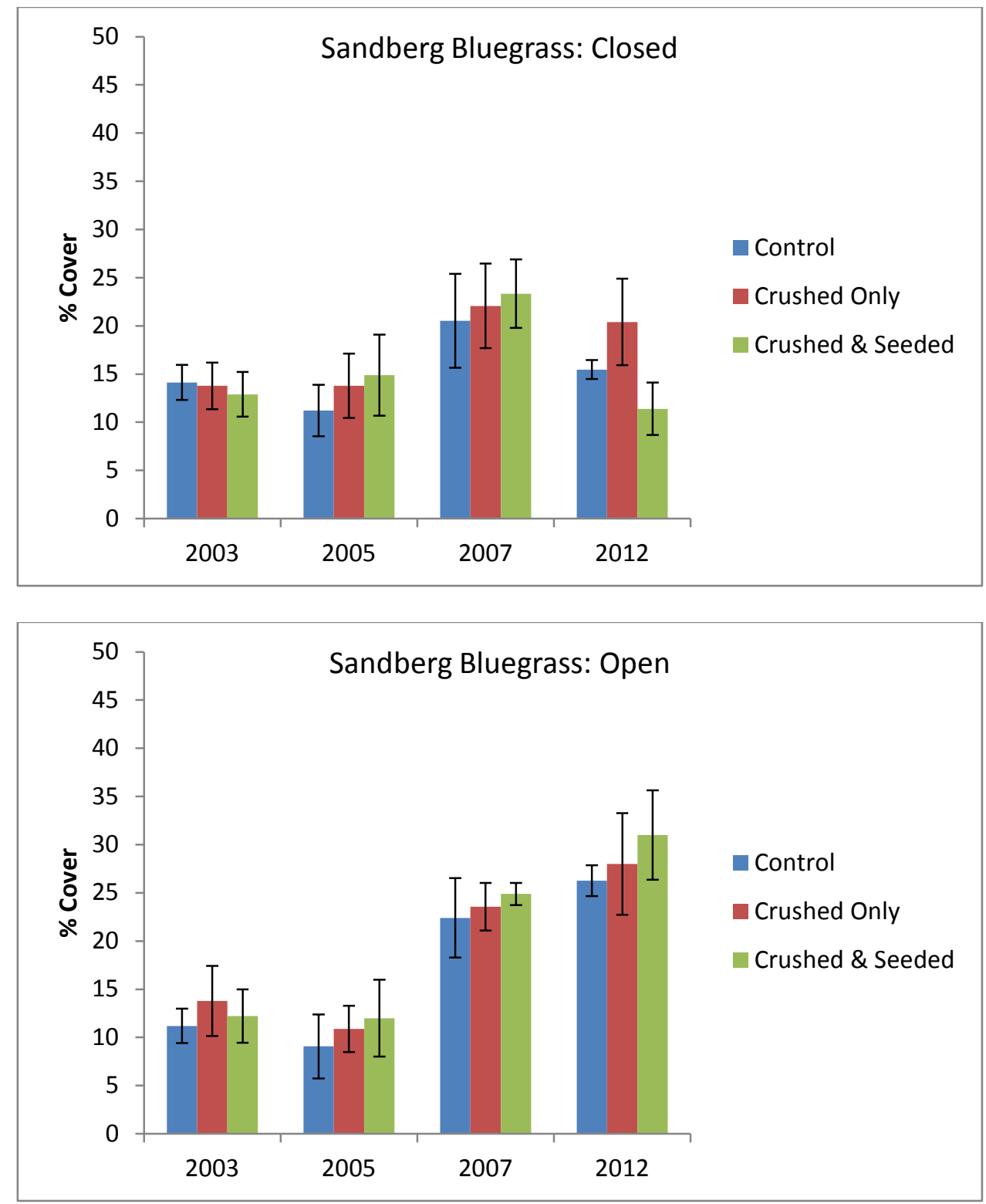

Figure 7. Response of Sandberg bluegrass cover to 3 treatments closed and open to livestock grazing. Bars represent mean \% cover values ( $n=5$ sites) and error bars represent $95 \%$ confidence intervals. 

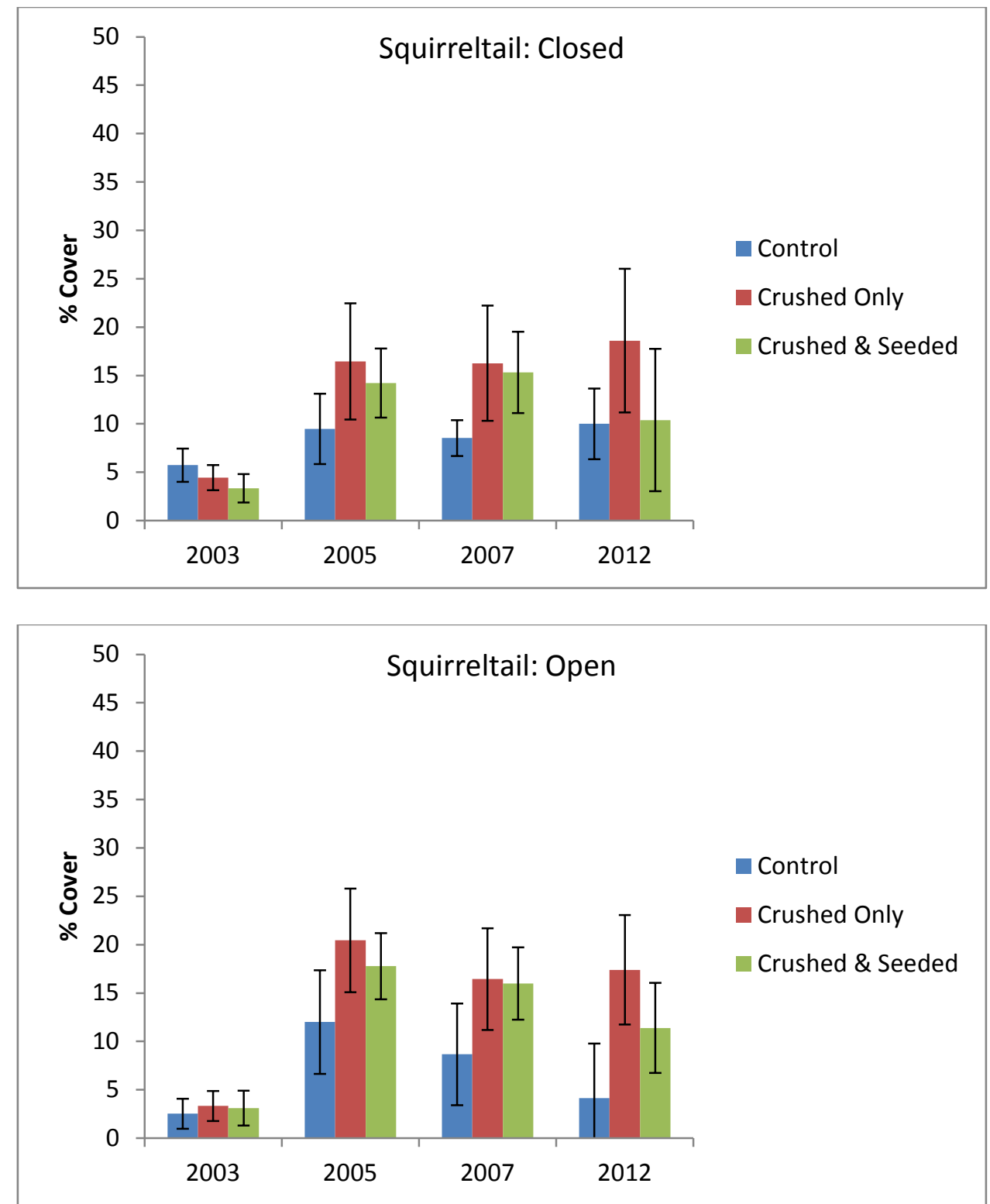

Figure 8. Response of squirreltail cover to 3 treatments closed and open to livestock grazing. Bars represent mean $\%$ cover values ( $n=5$ sites) and error bars represent $95 \%$ confidence intervals. 

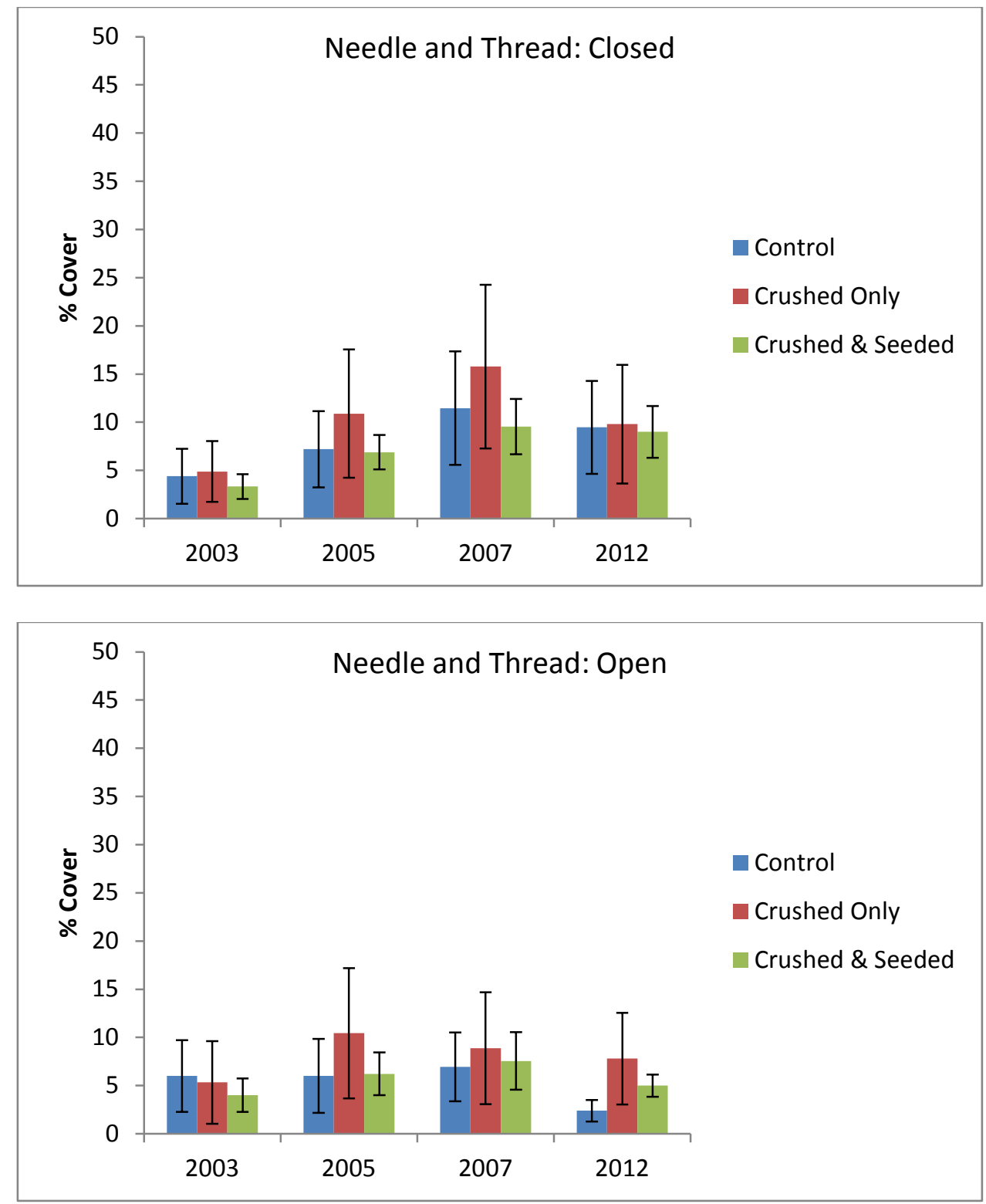

Figure 9. Response of needle and thread cover to 3 treatments closed and open to livestock grazing. Bars represent mean $\%$ cover values ( $n=5$ sites) and error bars represent $95 \%$ confidence intervals. 

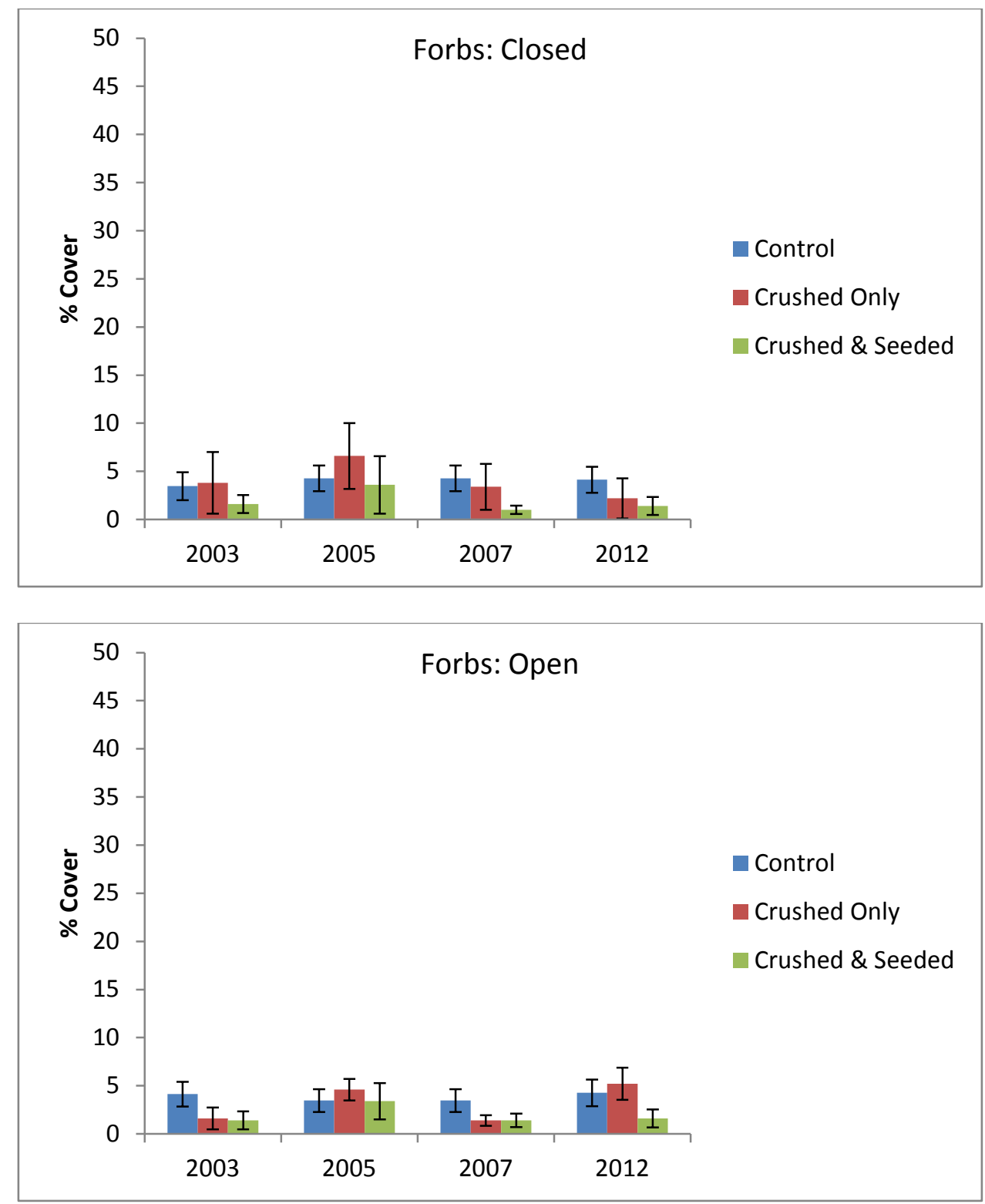

Figure 10. Response of forb cover to 3 treatments closed and open to livestock grazing. Bars represent mean $\%$ cover values ( $n=5$ sites) and error bars represent $95 \%$ confidence intervals. 

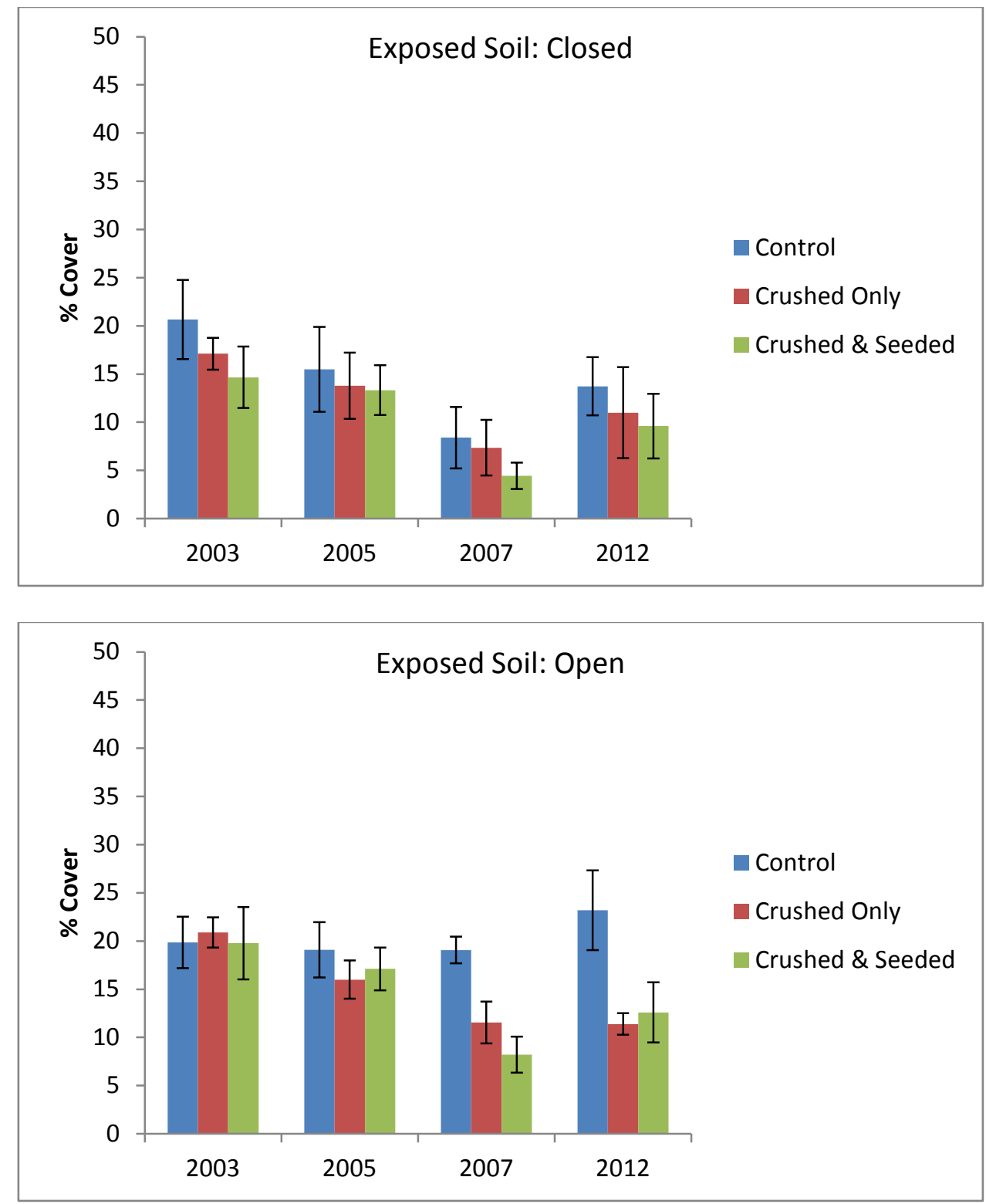

Figure 11. Response of exposed soil cover to 3 treatments closed and open to livestock grazing. Bars represent mean $\%$ cover values ( $n=5$ sites) and error bars represent $95 \%$ confidence intervals. 

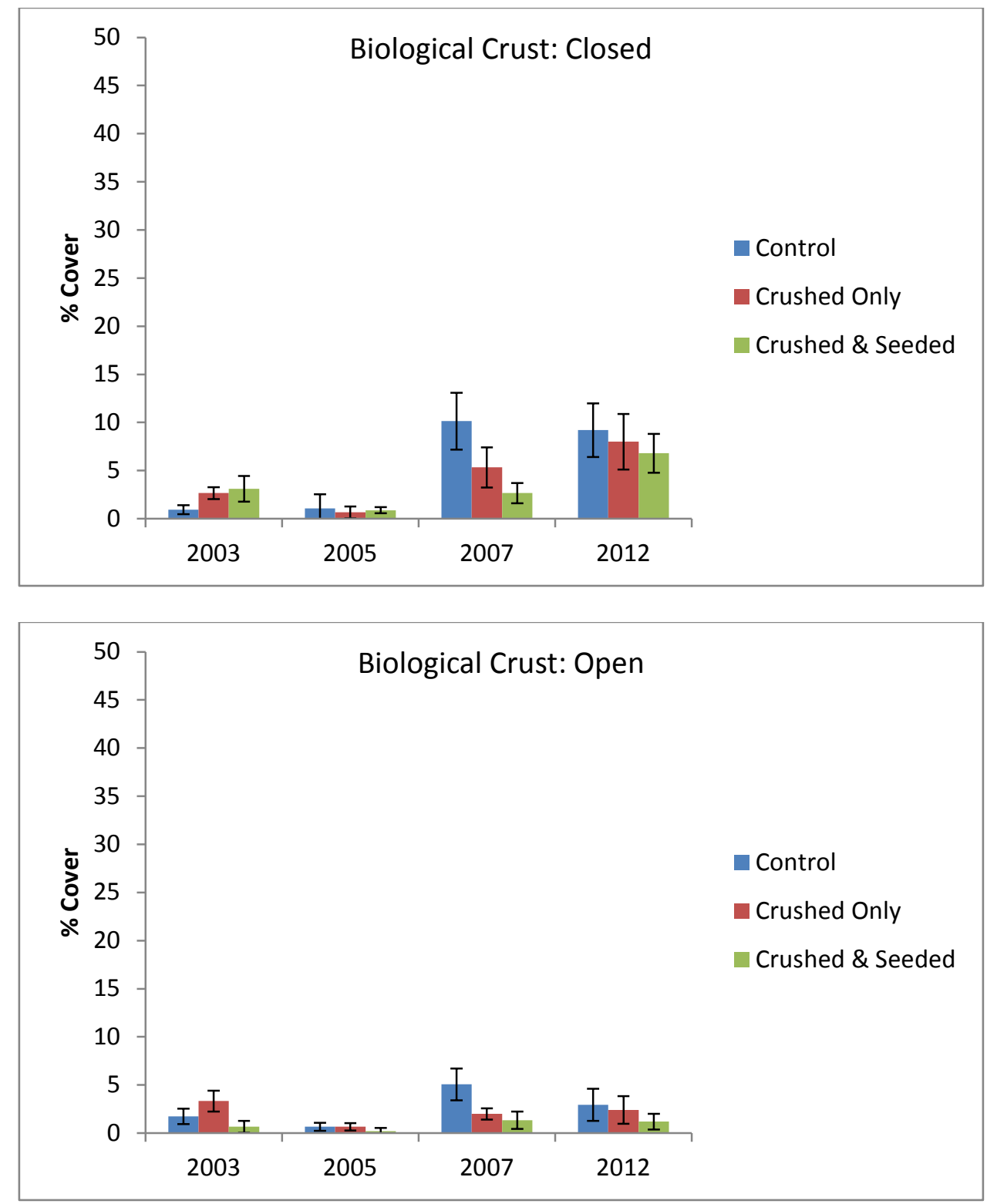

Figure 12. Response of biological crust cover to 3 treatments closed and open to livestock grazing. Bars represent mean $\%$ cover values ( $n=5$ sites) and error bars represent $95 \%$ confidence intervals. 


\section{DISCUSSION}

In sagebrush steppe, even though arid, there can be substantial variation among species in response to environmental variation. Because water availability is highly variable in time, response of vegetation to type and intensity of disturbance can take a long time in an arid environment (Anderson and Inouye 2001). There can be 2-5 year lags between patterns in precipitation and vegetation responses in Wyoming big sagebrush communities (Anderson and Inouye 2001). Abundance of perennial bunchgrasses (cover, biomass, density) commonly doesn't track precipitation (Anderson and Inouye 2001, Passey et al. 1982, West et al. 1979). Vegetation response to protection from grazing can also take decades (Valone et al. 2001, Yeo 2005). So I expected that vegetation response in this experiment might not be straightforward.

Estimated cover of Wyoming big sagebrush on control sites, both open to livestock grazing and closed, increased from 2003 to 2012 (17-19\% in 2003, 23-25\% in 2012). Favorable weather as evidenced by above average spring precipitation in 7 of the last dozen years (2004-2006, 2009-2012) likely contributed to the positive growing conditions. Anderson and Inouye (2001) documented a 3-year lag period between growth of Wyoming big sagebrush and precipitation on the Idaho National Laboratory (INL) in the absence of grazing. That also may be the case here with sagebrush cover increases in 2007 and 2012 following earlier wet springs.

Mechanical crushing reduced Wyoming big sagebrush cover from an average of $19 \%$ in 2003 to $7 \%$ in 2005; a reduction of $63 \%$. By 2012, 9 growing seasons post-treatment, average big sagebrush cover on crushed sites had increased to 11\%; an increase from 2005 of $42 \%$. This clearly is much faster recovery than from prescribed burning. Bunting et al. (1987) reported that Wyoming big sagebrush can take $40-$ 80 years to recover after burning. Although most crushed sites still are well below pre-treatment cover values, if sagebrush cover trends continue, I expect that Wyoming big sagebrush cover on crushed areas should be within the range of cover values recommended for greater sage-grouse habitat within the next decade. Guidelines for greater sage-grouse habitat recommend 15-25\% sagebrush cover in arid sagebrush steppe communities similar to that studied here (Connelly et al. 2000, Hagen et al. 2007, Stiver et al. 2010). In 2012 at 4 of the crushed only sites, Wyoming big sagebrush cover values exceeded the recommended 15\% lower threshold for greater sage-grouse habitat (range: $16-20 \%$ cover). However, two sites showed continued decline from 2005 cover values so there is some uncertainty about both the rate and amount of recovery.

In northern Utah, Summers (2005) followed responses to crushing with an aerator for 2 years posttreatment in a Wyoming big sagebrush/western wheatgrass (Pascopyrum smithii)-Sandberg bluegrass community. Crushing reduced Wyoming big sagebrush cover from $20 \%$ to $2 \%$. After 2 years, annual leader lengths of sagebrush on treated areas were significantly longer than on controls while sagebrush density was about half that of controls (Summers 2005). So sagebrush responded with increased growth, and very low cover values did not equate to very low plant density suggesting that sagebrush was poised to expand cover faster than cover values alone might reflect.

The results of the current study indicate that livestock grazing was suppressing growth (cover) of the larger grasses - bluebunch wheatgrass, needle and thread, and squirreltail. This isn't a surprising result other studies show that livestock grazing results in less cover, lower stature, and less biomass for plants selected by livestock (e.g. Briske and Richards 1995, Yeo 2005, Davies et al. 2010).

In the absence of livestock grazing (closed sites) bluebunch wheatgrass increased on all 3 types of treatments (control, crushed only, crushed \& seeded) following improved growing conditions in 2004- 
2006. Monsen et al. (2004) reported that bluebunch wheatgrass seed germinate fairly uniformly and mature stands can develop in 2-3 years following seeding so a lag period before cover increases is expected. Bluebunch wheatgrass can be restored with protection from disturbance (livestock grazing) if residual plants remain (Anderson and Inouye 2001). In the Pahsimeroi project area prior to treatments, wheatgrass was sparse across the project area and so seed from existing plants also would have been sparse. On the INL, recovery in the abundance of grasses was not correlated with rainfall; rather cover of grasses reflected the changing availability of seed as depleted populations increased in size resulting in exponential increases in grass cover (Anderson and Holte 1981). Low availability of plants to provide seed on controls and crushed only sites apparently reduced new seedling density although all treatments suggest a trend of increasing bluebunch wheatgrass cover between 2003 and 2012. Some sites beginning with very low cover values did respond with substantially increased cover values over time. This suggests that as bluebunch wheatgrass increases across the project area, the rate of cover increase may be exponential as the availability of seed increases; yet, the distribution of newly formed stands may be patchy. Areas open to livestock grazing may not recover as rapidly or to the same levels as areas where livestock are absent.

Crushing sagebrush without seeding, intended to reduce competition from big sagebrush, apparently had limited and possibly no effect on bluebunch wheatgrass cover within the time frame of this study. Seeding with crushing provided the most consistent and largest cover response. Seeding jump-started growth that, otherwise, likely would have taken much longer because of the paucity of established plants to provide seed. Removing livestock resulted in increased bluebunch wheatgrass cover over the 9 years regardless of treatment. Wheatgrass did increase on a few areas open to livestock but averages were less than half that found within exclosures.

Indian ricegrass comprised $10 \%$ of the seed mix yet there was no evidence of any response to seeding, treatments, or exclusion of livestock grazing. Indian ricegrass has a complex dormancy which slows establishment of seeded stands and can produce erratic stand development (Monsen et al. 2004). The rangeland drill depth settings should have been more favorable for Indian ricegrass than bluebunch wheatgrass so that is unlikely to be a factor in the apparent failure of ricegrass to establish (Monsen et al. 2004, Lambert 2005). Indian ricegrass doesn't do well with competition. However, the apparent complete absence of development from seed suggests that ricegrass either did not germinate or seedlings did not survive, nor did reduction of sagebrush improve very sparse stands of Indian ricegrass sufficiently within the time studied. Again, the scarcity of seed will result in very slow recovery initially.

Cover of Sandberg bluegrass was similar among treatments during 2003 and 2005, then cover surged in 2007. This was a drought year, very hot while sampling, and on open sites, cattle had been grazing. Why was there a surge in cover in a seemingly inhospitable year? Sandberg bluegrass initiates growth much earlier in the spring than the other grasses. It matures and sets seed in late spring or early summer. By the time cattle enter the pasture in late June or early July, bluegrass is senescent. It will green-up in the fall with favorable precipitation. The year 2006 had greater than usual fall moisture which may have contributed to higher cover values in 2007. In 2012, bluegrass again demonstrated an increase in cover on open sites compared to closed sites. This increase was particularly pronounced on crushed \& seeded open sites. Sandberg bluegrass is highly resistant to grazing and trampling (Monsen et al. 2004). Although favorable weather over the 9 years likely contributed to cover increases, the difference between closed and open sites in $\mathbf{2 0 1 2}$ may be due to increased competition from other grasses principally bluebunch wheatgrass in closed areas and Sandberg bluegrass's competitive advantage under grazing. 
Mechanical crushing appears to have improved growing conditions for squirreltail and needle and thread. Disturbance favored squirreltail with substantial increases particularly on crushed open sites where bluebunch wheatgrass didn't do well. On closed control sites, squirreltail did best on sites 6 and 8 which had little to no cover of bluebunch wheatgrass across the years. Squirreltail is a short-lived, early successional species that is very competitive (Jones 1998, Monsen et al. 2004). Squirreltail germinates readily, has rapid reproduction and maturity, and has excellent seed dispersal (Jones 1998). Establishment of squirreltail may facilitate the establishment of the longer-lived, slower establishing bluebunch wheatgrass (Jones 1998).

Needle and thread also seems to be repressed by competition from other plants and seems to be more greatly impacted by livestock grazing than squirreltail. Growth of needle and thread surged in 2005 with favorable precipitation and continued into 2007 with increased cover. It increased most substantially on crushed only sites suggesting that reduced competition from big sagebrush enhanced its growth and establishment. Needle and thread is one of the first species to disappear with overgrazing and one of the first to respond and reoccupy native communities with rest from grazing (Monsen et al. 2004). But needle and thread cover also increased on both open and fenced sites likely in response to favorable precipitation.

Forbs as yet haven't shown a discernible response to removal of livestock or crushing treatments. In other studies I've conducted in the area, I've found a significant, positive correlation between bluebunch wheatgrass cover and forb cover (unpublished data). I expect that as bluebunch wheatgrass cover increases that forb cover also will increase to some upper limit and likely with some lag period.

Crushing reduced the cover of biological soil crusts compared to untreated areas. Although the use of tractors may cause some mortality of biotic crusts, by treating at times when the soil crust is moist damage may be lessened (Belnap 2000). Treatments occurred in November 2003 after a recent snowfall. Soils were moist and cold. However, noticeable cover increases in 2007 and subsequently is encouraging. This was most evident on sites closed to livestock that showed a 3- to 7-fold greater average cover in 2012 compared to sites open to livestock. Crust cover values mostly remained similar across the years on open sites from 2003 through 2012. This positive response probably is in part due to increased rainfall and decreased arid periods in most years of the study. But clearly livestock trampling is suppressing the recovery of biotic crust cover values on open sites.

Areas adjacent to crushed treatments improved if the treated area improved in most but not all cases. This was most evident within exclosures. Viewing an aerial image of the project area (USDA Farm Service Agency 2012), the exclosures consistently show markedly darker than adjacent open areas. Based on my results, I suspect that this is an indication of greater live and residual vegetation cover, and biological crust.

Favorable weather conditions, in particular, unusually high precipitation in June 2009, likely contributed to good growing conditions which resulted in increased cover for major grasses and sagebrush over the period of study. Improved livestock management since the mid-1990s with better livestock distribution as a result of additional fencing and water developments during the past decade may also have contributed to improved range condition (P. Redick, BLM, personal communication).

\section{Management Recommendations}

Clearly, double-pass crushing and drill seeding in combination with livestock removal resulted in excellent establishment of bluebunch wheatgrass along with increased cover of other taller grasses. The 
Challis FO proposes to restore an additional 142 ha (350 ac) within the project area based on the apparent success of this project. Even though Wyoming big sagebrush appears to be recovering, I recommend that treatments be done in 30-m wide strips as done for this project or that treatments be done in blocks (possibly $\sim 4$ ha) to retain nesting cover and structure for greater sage-grouse and other passerine birds as well as cover for pronghorn fawns and pronghorn winter forage. Once the treated blocks support sagebrush cover that is comparable to cover in untreated blocks, the untreated blocks could subsequently be treated.

I think the seed mix should be changed from that used in this project. Indian ricegrass comprised $10 \%$ of the seed mix yet there was no evidence that seeding increased its cover. Instead, I recommend that the seed mix be changed to include bluebunch wheatgrass, squirreltail, needle and thread, and some upright native forbs such as daisies, Indian paintbrush, longleaf phlox (Phlox longifolia), and rockcress (Arabis spp.). All these species already occur within the project area. I think this would not only improve seeding success, it would improve species diversity along with greater forb cover more quickly than has occurred so far with this project.

Crushed \& seeded sites were protected from livestock grazing for 1 year following treatment. Based on the results of this study, this does not provide sufficient time for bluebunch wheatgrass to establish as vigorously as longer protection from livestock grazing. Monsen et al. (2004) recommend a minimum of 4 years of nonuse by livestock following seeding in dry Wyoming big sagebrush communities. In situations when precipitation is below average during the first few years, they recommend an additional 1-3 years of nonuse. Although the crushed \& seeded areas were small in this project, it was apparent that cattle were selecting seeded areas and even if the seeded area was larger, the success of the seeding would be jeopardized if cattle were allowed to graze before bluebunch wheatgrass has become well established. As noted above, there typically is a 3-year lag after seeding before bluebunch wheatgrass stands begin to develop. My data indicate that seedings within exclosures didn't take off until about 2007 after 2 years of favorable rainfall. Growing season weather patterns can't be predicted from one year to the next so allowing a longer period for seeding establishment in this arid landscape seems judicious. With the vagaries of weather and this lag, it makes sense to be cautious and allow at least 4- 5 years after seeding before livestock are returned to the treated area.

Crushed \& seeded sites open to livestock grazing achieved similar cover values of bluebunch wheatgrass as control sites closed to livestock. So simply removing livestock could achieve substantial increases in principal grass cover without the expense of crushing \& seeding. My expectation is that if livestock were removed from the West Flat Pasture and precipitation were favorable that bluebunch wheatgrass cover would increase across the community although with some patches taking longer to increase cover because of localized conditions and the paucity of seed sources. However, increased herbaceous cover after removing livestock isn't a given and may require decades for meaningful improvement (West et al. 1984, West 2000, Yeo 2005). Permanently removing livestock use also could preclude some management options and possibly increase the risk of wildfire (Davies et al. 2010) so managed disturbance combined with light grazing (sensu Holechek et al. 2001) and possibly periodic nonuse may be the best option for these impoverished sagebrush steppe communities.

Using disturbance to revitalize the herbaceous community carried the concern that soil disturbance from the crushing could result in the establishment or expansion of noxious weeds or other invasive species, principally cheatgrass. Cheatgrass remained rare across the project area despite the extensive soil disturbance resulting from crushing, and did not invade crushed only sites (the area most susceptible to invasion). However, cheatgrass was rare prior to the project and rarely exists in dense patches anywhere within the Challis FO area. 
Elk selected for seeded sites and other sites with improved bluebunch wheatgrass cover, as did cattle, although elk were able to gain access inside livestock exclosures. Based on sign (fecal pellets and tracks), elk seemed implicated in transporting cheatgrass within exclosures - so despite cheatgrass being rare, there is the potential for expanding and increasing cheatgrass by native herbivores. This would need to be monitored on a larger project as proposed. I would be reluctant to implement mechanical crushing in areas where cheatgrass is abundant unless there were additional measures undertaken to effectively control cheatgrass prior to seeding efforts.

In summary then, I recommend the following for using mechanical crushing and seeding for range improvement in Wyoming big sagebrush/bluebunch wheatgrass communities with an impoverished herb layer:

1. provide a period of nonuse of 4-5 years following crushing \& seeding as other authors have recommended and even longer if special circumstances occur such as drought,

2. institute conservative livestock management for the first 10 years or so that prioritizes recovery and establishment of vigorous native plant communities in treated areas (e.g. light grazing in mid to late summer following seed set of bluebunch wheatgrass), and

3. in areas where cheatgrass invasion is a concern, managers should consider not implementing this restoration approach unless other methods are available for controlling cheatgrass.

For the West Flat Pasture, I encourage the Challis FO to retain the experimental exclosures as reference sites to compare with the proposed expanded crushing and seeding restoration project as well as an ongoing record of plant community responses to nonuse by livestock (controls) and the trajectory of recovery of shrubs, grasses, and forbs in response to the existing treatments. The weather station has been useful in calibrating the project area to the May, Idaho weather station but maintenance and data collection have been difficult being so remote. I don't know if maintaining the station in the project area continues to be useful or not. Possibly an agreement with someone local, such as the allotment permittee, to maintain the station could continue its useful life.

\section{ACKNOWLEDGEMENTS}

This project was funded over the years through contracts with the Idaho BLM, the Idaho Department of Fish and Game via an Assistance Agreement with the BLM, and a BLM Challenge Cost Share Agreement. Signe Sather-Blair and Alan Sands recognized the importance of this project to land management, and it was largely through their continued support that funding was obtained over the years. Paul Makela continued this tradition of support in recent years. Bill Diage and Jerry Gregson helped promote the usefulness of this project to Challis FO staff. Challis FO staff contributed to the development of the project, conducted the Environmental Assessment process, built the enclosure fences, and Jerry and Bill helped me install the project weather station. In particular, Leigh Redick supervised the deployment of the Lawson aerator and seeding with the rangeland drill, developed the soils-based seed mixture, supervised the construction of the exclosures and electric fencing during the first year post-treatment, and has kept the project weather station in operation over many years. Alexis Carroll, Alan Sands, and Jette Morache provided competent assistance in the field. I also wish to thank the staff at Spectrum Technologies, supplier of the meteorological station, for support over the years with the hardware and software for the weather station. Paul Makela, Jette Morache, Peggy Redick, Alan Sands, and Bart Zwetzig contributed very useful comments to an earlier draft of this report. 


\section{LITERATURE CITED}

Anderson, J.E., and K.E. Holte. 1981. Vegetation development over 25 years without grazing on sagebrush-dominated rangeland in southeastern Idaho. Journal of Range Management 34:2529.

, and R.S. Inouye. 2001. Landscape-scale changes in plant species abundance and biodiversity of a sagebrush steppe over 45 years. Ecological Monographs 71:531-556.

Belnap, J. 2000. Structure and function of biological soil crusts. Pages 55-62 in P. G. Entwistle, A. M. DeBolt, J. H. Kaltenecker, and K. Steenhof, compilers. Proceedings: sagebrush steppe ecosystems symposium. Bureau of Land Management Publication No. BLM/ID/PT-001001+1150, Boise, Idaho.

Briske, D.D., and J.H. Richards. 1995. Plant responses to defoliation: a physiological, morphological, and demographic evaluation. Pages 635-710 in Wildland plants: physiological ecology and developmental morphology, Bedunah, D.J., and R. E. Sosebee, eds. Society for Range Management. Denver, CO.

Bunting, S. C., B. M. Kilgore, and C. L. Bushey. 1987. Guidelines for prescribed burning sagebrush steppe rangelands in the northern Great Basin. USDA Forest Service General Technical Report INT-231.

Connelly, J. W., M. A. Schroeder, A. R. Sands, and C. E. Braun. 2000. Guidelines to manage sage grouse populations and their habitats. Wildlife Society Bulletin 28(4):967-985.

Davies, K.W., J.D. Bates, T.J. Svejcar, and C.S. Boyd. 2010. Effects of long-term livestock grazing on fuel characteristics in rangelands: an example from the sagebrush steppe. Rangeland Ecology and Management 63:662-669.

Eddleman, L. E., and P. S. Doescher. 2000. Current issues in the sagebrush steppe ecosystem: grazing, fire, and other disturbances. Pages 41-42 in P. G. Entwistle, A. M. DeBolt, J. H. Kaltenecker, and K. Steenhof, compilers. Proceedings: sagebrush steppe ecosystems symposium. Bureau of Land Management Publication No. BLM/ID/PT-001001+1150, Boise, Idaho.

Hagen, C.A., J.W. Connelly, and M.A. Schroeder. 2007. A meta-analysis of greater sage-grouse Centrocercus urophasianus nesting and brood-rearing habitats. Wildlife Biology 13: 42-50, Suppl. 1.

Hann, W.J., J.L. Lyons, M.G. Karl, P.F. Hessburg, R.E. Keane, D.G. Long, J.P. Menakis, C.H. McNicholl, S.G. Leonard, R.A. Gravenmier, and B.G. Smith. 1997. Landscape dynamics of the Basin. Chapter 3 in T.M Quigley and S.J. Arbelbide, technical editors. An assessment of ecosystem components in the Interior Columbia River Basin and portions of the Klamath and Great Basins. Vol. II. USDA Forest Service, PNW-GTR-405. Pacific Northwest Research Station, Portland, OR.

Holechek, J.L, R.D. Pieper, and C.H. Herbel. 2001. Range management: principles and practices, $4^{\text {th }}$ ed. Prentice Hall, Upper Saddle River, NJ.

Jones, T.A. 1998. Viewpoint: the present status and future prospects of squirreltail research. Journal of Range Management 51:326-331. 
Lambert, S.M. 2005. Guidebook to the seeds of native and non-native grasses, forbs and shrubs of the Great Basin. Idaho BLM Technical Bulletin 2005-04.

Monsen, S.B., R. Stevens, and N.L. Shaw, comp. 2004. Restoring western ranges and wildlands. USDA Forest Service General Technical Report RMRS-GTR-136. Fort Collins, CO.

Natural Resources Conservation Service. 2002. Custer-Lemhi Counties, Idaho soil survey. USDA Natural Resources Conservation Service, Boise, Idaho.

Noss, R.F., E.T. LaRoe, and J.M. Scott. 1995. Endangered ecosystems of the United States: a preliminary assessment of loss and degradation. Biological Report No. 28. National Biological Service, Washington, D. C.

Paige, C., and S. A. Ritter. 1999. Birds in a sagebrush sea: managing sagebrush habitats for bird communities. Partners in Flight Western Working Group, Boise, Idaho.

Passey, H.B., V.K. Hugie, E.W. Williams, and D.E. Ball. 1982. Relationships between soil, plant community, and climate on rangelands of the Intermountain West. USDA Soil Conservation Service Technical Bulletin Number 1669, Washington, D.C.

Pellant, M., P. Shaver, D.A. Pyke, and J.E. Herrick. 2000. Interpreting indicators of rangeland health version 3. USDI Bureau of Land Management Technical Reference 1734-6.

Pyke, D.A. 2000. Invasive exotic plants in sagebrush ecosystems of the intermountain west. Pages 43-54 in P. G. Entwistle, A. M. DeBolt, J. H. Kaltenecker, and K. Steenhof, compilers. Proceedings: sagebrush steppe ecosystems symposium. Bureau of Land Management Publication No. BLM/ID/PT-001001+1150, Boise, Idaho.

Sands, A. R., S. Sather-Blair, and V. Saab. 2000. Sagebrush steppe wildlife: historical and current perspectives. Pages 27-34 in P. G. Entwistle, A. M. DeBolt, J. H. Kaltenecker, and K. Steenhof, compilers. Proceedings: sagebrush steppe ecosystems symposium. Bureau of Land Management Publication No. BLM/ID/PT-001001+1150, Boise, Idaho.

Society for Range Management. 1999. A glossary of terms used in range management. Society for Range Management, Denver, CO.

Stiver, S.J., E.T Rinkes, and D.E. Naugle. 2010. Sage-grouse habitat assessment framework. Unpublished Report. U.S. Bureau of Land Management, Idaho State Office, Boise, Idaho.

Summers, D.D. 2005. Vegetation response of a Wyoming big sagebrush (Artemisia tridentata wyomingensis) community to six mechanical treatments in Rich County, Utah. M.S. Thesis, Brigham Young University, Provo, UT.

Valone, T.J., M. Meyer, J.H. Brown, and R.M. Crew. 2001. Timescale of perennial grass recovery in desertified arid grasslands following livestock removal. Conservation Biology 16:995-1002.

Walter, H., E. Harnickell, and D. Mueller-Dombois. 1975. Climate-diagram maps of the individual continents and the ecological climatic regions of the earth. Springer-Verlag, Berlin.

West, N. E. 2000. Synecology and disturbance regimes of sagebrush steppe ecosystems. Pages 15-26 in P. G. Entwistle, A. M. DeBolt, J. H. Kaltenecker, and K. Steenhof, compilers. Proceedings: 
sagebrush steppe ecosystems symposium. Bureau of Land Management Publication No. BLM/ID/PT-001001+1150, Boise, Idaho.

, K.H. Rea, and R.O. Harniss. 1979. Plant demographic studies in sagebrush-grass communities of southeastern Idaho. Ecology 60:376-388.

F. D. Provenza, P. S. Johnson, and M. K. Owens. 1984. Vegetation change after 13 years of livestock grazing exclusion on sagebrush semidesert in west central Utah. Journal of Range Management 37(3):262-264.

Yeo, J. J. 2005. Effects of grazing exclusion on rangeland vegetation and soils, east central Idaho. Western North American Naturalist 65:91-102. 


\section{APPENDIX A}

Table A.1. Wyoming big sagebrush percent cover estimates by treatment, $2003-2012$.

\begin{tabular}{r|rrrrrrrr} 
& \multicolumn{9}{|c}{ Closed } & \multicolumn{9}{c}{ Control } \\
\cline { 2 - 10 } Site & 2003 & 2005 & 2007 & 2012 & 2003 & 2005 & 2007 & 2012 \\
\hline 3 & 19 & 23 & 19 & 20 & 19 & 18 & 22 & 20 \\
6 & 21 & 25 & 26 & 27 & 18 & 21 & 24 & 21 \\
8 & 16 & 25 & 27 & 38 & 21 & 21 & 28 & 29 \\
11 & 17 & 9 & 18 & 17 & 19 & 13 & 19 & 26 \\
13 & 21 & 14 & 14 & 22 & 11 & 9 & 19 & 18 \\
\hline \multirow{2}{*}{ mean } & & & & & & & & \\
& 19 & 19 & $\mathbf{2 1}$ & $\mathbf{2 5}$ & $\mathbf{1 7}$ & $\mathbf{1 6}$ & $\mathbf{2 2}$ & $\mathbf{2 3}$
\end{tabular}

\begin{tabular}{r|rrrrrrrr} 
& \multicolumn{9}{c}{ Closed } & \multicolumn{9}{c}{ Crushed Only } \\
\cline { 2 - 10 } Site & 2003 & 2005 & 2007 & 2012 & 2003 & 2005 & 2007 & 2012 \\
\hline 2 & 11 & 6 & 12 & 9 & 20 & 6 & 8 & 20 \\
4 & 26 & 12 & 8 & 10 & 11 & 6 & 12 & 19 \\
7 & 23 & 4 & 17 & 20 & 21 & 4 & 4 & 16 \\
10 & 10 & 7 & 2 & 1 & 14 & 4 & 6 & 11 \\
12 & 32 & 9 & 11 & 11 & 19 & 12 & 12 & 13 \\
\hline & & & & & & & & \\
mean & $\mathbf{2 0}$ & $\mathbf{8}$ & $\mathbf{1 0}$ & $\mathbf{1 0}$ & $\mathbf{1 7}$ & $\mathbf{6}$ & $\mathbf{8}$ & $\mathbf{1 6}$
\end{tabular}

\begin{tabular}{|c|c|c|c|c|c|c|c|c|}
\hline \multirow[b]{3}{*}{ Site } & \multicolumn{8}{|c|}{ Crushed \& Seeded } \\
\hline & \multicolumn{4}{|c|}{ Closed } & \multicolumn{4}{|c|}{ Open } \\
\hline & 2003 & 2005 & 2007 & 2012 & 2003 & 2005 & 2007 & 2012 \\
\hline 1 & 19 & 6 & 16 & 4 & 28 & 7 & 16 & 8 \\
\hline 5 & 19 & 7 & 7 & 10 & 11 & 4 & 10 & 13 \\
\hline 9 & 21 & 7 & 13 & 12 & 17 & 8 & 4 & 3 \\
\hline 14 & 26 & 10 & 14 & 10 & 13 & 7 & 8 & 11 \\
\hline 15 & 28 & 2 & 16 & 12 & 18 & 7 & 11 & 8 \\
\hline mean & 22 & 6 & 13 & 10 & 17 & 6 & 10 & 9 \\
\hline
\end{tabular}


Table A.2. Bluebunch wheatgrass percent cover estimates by treatment, $2003-2012$.

\begin{tabular}{r|rrrrrrrr} 
& \multicolumn{9}{c}{ Closed } & \multicolumn{7}{c}{ Control } \\
\cline { 2 - 10 } \multicolumn{1}{c|}{ Site } & 2003 & 2005 & 2007 & 2012 & 2003 & 2005 & 2007 & 2012 \\
\hline 3 & 3 & 16 & 21 & 25 & 3 & 19 & 12 & 11 \\
6 & 1 & 0 & 0 & 0 & 1 & 0 & 0 & 0 \\
8 & 0 & 0 & 0 & 0 & 1 & 0 & 0 & 3 \\
11 & 1 & 27 & 14 & 27 & 0 & 1 & 1 & 1 \\
13 & 2 & 3 & 16 & 14 & 1 & 18 & 11 & 10 \\
\hline \multirow{2}{*}{ mean } & $\mathbf{1}$ & $\mathbf{9}$ & $\mathbf{1 0}$ & $\mathbf{1 3}$ & $\mathbf{1}$ & $\mathbf{8}$ & $\mathbf{5}$ & $\mathbf{5}$
\end{tabular}

\begin{tabular}{|c|c|c|c|c|c|c|c|c|}
\hline \multirow[b]{3}{*}{ Site } & \multicolumn{8}{|c|}{ Crushed Only } \\
\hline & \multicolumn{4}{|c|}{ Closed } & \multicolumn{4}{|c|}{ Open } \\
\hline & 2003 & 2005 & 2007 & 2012 & 2003 & 2005 & 2007 & 2012 \\
\hline 2 & 3 & 9 & 27 & 40 & 1 & 3 & 14 & 7 \\
\hline 4 & 0 & 2 & 2 & 8 & 0 & 0 & 1 & 6 \\
\hline 7 & 0 & 0 & 0 & 0 & 0 & 0 & 0 & 0 \\
\hline 10 & 1 & 9 & 10 & 14 & 1 & 3 & 1 & 1 \\
\hline 12 & 1 & 0 & 0 & 0 & 0 & 0 & 0 & 0 \\
\hline mean & 1 & 4 & 8 & 12 & 0 & 1 & 3 & 3 \\
\hline
\end{tabular}

\begin{tabular}{|c|c|c|c|c|c|c|c|c|}
\hline \multirow[b]{3}{*}{ Site } & \multicolumn{8}{|c|}{ Crushed \& Seeded } \\
\hline & \multicolumn{4}{|c|}{ Closed } & \multicolumn{4}{|c|}{ Open } \\
\hline & 2003 & 2005 & 2007 & 2012 & 2003 & 2005 & 2007 & 2012 \\
\hline 1 & 4 & 10 & 30 & 47 & 6 & 9 & 23 & 28 \\
\hline 5 & 2 & 3 & 34 & 42 & 2 & 0 & 1 & 7 \\
\hline 9 & 3 & 17 & 24 & 33 & 3 & 16 & 11 & 8 \\
\hline 14 & 0 & 0 & 13 & 17 & 0 & 0 & 9 & 13 \\
\hline 15 & 0 & 0 & 20 & 28 & 0 & 0 & 4 & 4 \\
\hline mean & 2 & 6 & 24 & 33 & 2 & 5 & 10 & 12 \\
\hline
\end{tabular}


Table A.3. Sandberg bluegrass percent cover estimates by treatment, $2003-2012$.

\begin{tabular}{|c|c|c|c|c|c|c|c|c|}
\hline \multirow[b]{3}{*}{ Site } & \multicolumn{8}{|c|}{ Control } \\
\hline & \multicolumn{4}{|c|}{ Closed } & \multicolumn{4}{|c|}{ Open } \\
\hline & 2003 & 2005 & 2007 & 2012 & 2003 & 2005 & 2007 & 2012 \\
\hline 3 & 13 & 10 & 14 & 15 & 9 & 5 & 25 & 23 \\
\hline 6 & 13 & 15 & 25 & 18 & 14 & 10 & 19 & 30 \\
\hline 8 & 15 & 16 & 31 & 14 & 15 & 18 & 33 & 25 \\
\hline 11 & 19 & 10 & 19 & 16 & 9 & 5 & 20 & 27 \\
\hline 13 & 11 & 5 & 13 & 15 & 9 & 7 & 15 & 26 \\
\hline mean & 14 & 11 & 21 & 15 & 11 & 9 & 22 & 26 \\
\hline
\end{tabular}

\begin{tabular}{|c|c|c|c|c|c|c|c|c|}
\hline \multirow[b]{3}{*}{ Site } & \multicolumn{8}{|c|}{ Crushed Only } \\
\hline & \multicolumn{4}{|c|}{ Closed } & \multicolumn{4}{|c|}{ Open } \\
\hline & 2003 & 2005 & 2007 & 2012 & 2003 & 2005 & 2007 & 2012 \\
\hline 2 & 9 & 7 & 13 & 9 & 14 & 7 & 23 & 19 \\
\hline 4 & 14 & 10 & 20 & 29 & 23 & 9 & 24 & 28 \\
\hline 7 & 16 & 20 & 31 & 20 & 8 & 16 & 18 & 40 \\
\hline 10 & 19 & 16 & 19 & 22 & 12 & 9 & 29 & 21 \\
\hline 12 & 11 & 17 & 27 & 22 & 11 & 14 & 23 & 32 \\
\hline mean & 14 & 14 & 22 & 20 & 14 & 11 & 24 & 28 \\
\hline
\end{tabular}

\begin{tabular}{r|rrrrrrrr} 
& \multicolumn{8}{|c}{ Closed } \\
\cline { 2 - 9 } \multicolumn{1}{c|}{ Site } & 2003 & 2005 & 2007 & 2012 & 2003 & 2005 & 2007 & 2012 \\
\hline 1 & 19 & 18 & 22 & 8 & 10 & 6 & 23 & 21 \\
5 & 11 & 21 & 21 & 11 & 20 & 6 & 26 & 42 \\
9 & 12 & 6 & 21 & 7 & 11 & 12 & 23 & 30 \\
14 & 9 & 20 & 33 & 18 & 11 & 18 & 28 & 32 \\
15 & 13 & 10 & 19 & 13 & 9 & 19 & 24 & 30 \\
\hline \multirow{2}{*}{ mean } & 13 & 15 & $\mathbf{2 3}$ & $\mathbf{1 1}$ & $\mathbf{1 2}$ & $\mathbf{1 2}$ & $\mathbf{2 5}$ & $\mathbf{3 1}$
\end{tabular}


Table A.4. Squirreltail percent cover estimates by treatment, $2003-2012$.

\begin{tabular}{|c|c|c|c|c|c|c|c|c|}
\hline \multirow[b]{3}{*}{ Site } & \multicolumn{8}{|c|}{ Control } \\
\hline & \multicolumn{4}{|c|}{ Closed } & \multicolumn{4}{|c|}{ Open } \\
\hline & 2003 & 2005 & 2007 & 2012 & 2003 & 2005 & 2007 & 2012 \\
\hline 3 & 3 & 5 & 8 & 3 & 3 & 5 & 4 & 4 \\
\hline 6 & 10 & 16 & 13 & 17 & 5 & 15 & 14 & 5 \\
\hline 8 & 7 & 15 & 9 & 15 & 2 & 20 & 8 & 1 \\
\hline 11 & 5 & 3 & 7 & 5 & 1 & 14 & 14 & 9 \\
\hline 13 & 5 & 7 & 5 & 9 & 1 & 6 & 3 & 2 \\
\hline mean & 6 & 9 & 9 & 10 & 3 & 12 & 9 & 4 \\
\hline
\end{tabular}

\begin{tabular}{|c|c|c|c|c|c|c|c|c|}
\hline \multirow[b]{3}{*}{ Site } & \multicolumn{8}{|c|}{ Crushed Only } \\
\hline & \multicolumn{4}{|c|}{ Closed } & \multicolumn{4}{|c|}{ Open } \\
\hline & 2003 & 2005 & 2007 & 2012 & 2003 & 2005 & 2007 & 2012 \\
\hline 2 & 2 & 7 & 7 & 8 & 0 & 14 & 10 & 10 \\
\hline 4 & 8 & 20 & 17 & 11 & 3 & 27 & 11 & 16 \\
\hline 7 & 3 & 26 & 20 & 29 & 7 & 20 & 28 & 16 \\
\hline 10 & 4 & 6 & 8 & 11 & 2 & 10 & 10 & 12 \\
\hline 12 & 4 & 24 & 30 & 34 & 4 & 31 & 23 & 33 \\
\hline mean & 4 & 16 & 16 & 19 & 3 & 20 & 16 & 17 \\
\hline
\end{tabular}

\begin{tabular}{|c|c|c|c|c|c|c|c|c|}
\hline \multirow[b]{3}{*}{ Site } & \multicolumn{8}{|c|}{ Crushed \& Seeded } \\
\hline & \multicolumn{4}{|c|}{ Closed } & \multicolumn{4}{|c|}{ Open } \\
\hline & 2003 & 2005 & 2007 & 2012 & 2003 & 2005 & 2007 & 2012 \\
\hline 1 & 1 & 7 & 14 & 2 & 0 & 13 & 10 & 3 \\
\hline 5 & 7 & 13 & 8 & 3 & 4 & 27 & 12 & 7 \\
\hline 9 & 1 & 12 & 10 & 7 & 0 & 13 & 13 & 12 \\
\hline 14 & 3 & 17 & 23 & 31 & 6 & 19 & 20 & 23 \\
\hline 15 & 4 & 22 & 21 & 9 & 6 & 17 & 24 & 12 \\
\hline mean & 3 & 14 & 15 & 10 & 3 & 18 & 16 & 11 \\
\hline
\end{tabular}


Table A.5. Needle and thread percent cover estimates by treatment, $2003-2012$.

\begin{tabular}{|c|c|c|c|c|c|c|c|c|}
\hline \multirow[b]{3}{*}{ Site } & \multicolumn{8}{|c|}{ Control } \\
\hline & \multicolumn{4}{|c|}{ Closed } & \multicolumn{4}{|c|}{ Open } \\
\hline & 2003 & 2005 & 2007 & 2012 & 2003 & 2005 & 2007 & 2012 \\
\hline 3 & 7 & 11 & 12 & 12 & 7 & 7 & 12 & 3 \\
\hline 6 & 2 & 2 & 4 & 3 & 1 & 2 & 4 & 1 \\
\hline 8 & 0 & 0 & 0 & 0 & 0 & 0 & 1 & 0 \\
\hline 11 & 2 & 7 & 19 & 15 & 8 & 5 & 4 & 3 \\
\hline 13 & 11 & 15 & 22 & 18 & 15 & 16 & 14 & 5 \\
\hline mean & 4 & 7 & 11 & 9 & 6 & 6 & 7 & 2 \\
\hline
\end{tabular}

\begin{tabular}{|c|c|c|c|c|c|c|c|c|}
\hline \multirow[b]{3}{*}{ Site } & \multicolumn{8}{|c|}{ Crushed Only } \\
\hline & \multicolumn{4}{|c|}{ Closed } & \multicolumn{4}{|c|}{ Open } \\
\hline & 2003 & 2005 & 2007 & 2012 & 2003 & 2005 & 2007 & 2012 \\
\hline 2 & 12 & 18 & 31 & 18 & 11 & 22 & 23 & 13 \\
\hline 4 & 8 & 26 & 28 & 22 & 1 & 9 & 10 & 9 \\
\hline 7 & 1 & 2 & 3 & 0 & 0 & 0 & 0 & 0 \\
\hline 10 & 3 & 9 & 16 & 8 & 14 & 21 & 10 & 17 \\
\hline 12 & 0 & 0 & 1 & 1 & 0 & 0 & 1 & 0 \\
\hline mean & 5 & 11 & 16 & 10 & 5 & 10 & 9 & 8 \\
\hline
\end{tabular}

\begin{tabular}{r|rrrrrrrrr} 
& \multicolumn{8}{c}{ Closed } & \multicolumn{8}{c}{ Crushed \& Seeded } \\
\cline { 2 - 10 } Site & 2003 & 2005 & 2007 & 2012 & 2003 & 2005 & 2007 & 2012 \\
\hline 1 & 6 & 11 & 14 & 13 & 4 & 8 & 11 & 4 \\
5 & 1 & 6 & 7 & 6 & 3 & 7 & 8 & 7 \\
9 & 6 & 8 & 13 & 11 & 8 & 11 & 13 & 7 \\
14 & 2 & 3 & 10 & 3 & 0 & 2 & 2 & 3 \\
15 & 2 & 7 & 3 & 12 & 4 & 3 & 3 & 4 \\
\hline & & & & & & & & & \\
mean & $\mathbf{3}$ & $\mathbf{7}$ & $\mathbf{1 0}$ & $\mathbf{9}$ & $\mathbf{4}$ & $\mathbf{6}$ & $\mathbf{8}$
\end{tabular}


Table A.6. Forb percent cover estimates by treatment, 2003-2012.

\begin{tabular}{|c|c|c|c|c|c|c|c|c|}
\hline \multirow[b]{3}{*}{ Site } & \multicolumn{8}{|c|}{ Control } \\
\hline & \multicolumn{4}{|c|}{ Closed } & \multicolumn{4}{|c|}{ Open } \\
\hline & 2003 & 2005 & 2007 & 2012 & 2003 & 2005 & 2007 & 2012 \\
\hline 3 & 4 & 7 & 7 & 3 & 6 & 5 & 5 & 6 \\
\hline 6 & 2 & 2 & 2 & 3 & 1 & 2 & 2 & 5 \\
\hline 8 & 7 & 4 & 4 & 8 & 6 & 1 & 1 & 3 \\
\hline 11 & 2 & 5 & 5 & 3 & 3 & 3 & 3 & 1 \\
\hline 13 & 2 & 3 & 3 & 3 & 5 & 6 & 6 & 7 \\
\hline mean & 3 & 4 & 4 & 4 & 4 & 3 & 3 & 4 \\
\hline
\end{tabular}

\begin{tabular}{|c|c|c|c|c|c|c|c|c|}
\hline \multirow[b]{3}{*}{ Site } & \multicolumn{8}{|c|}{ Crushed Only } \\
\hline & \multicolumn{4}{|c|}{ Closed } & \multicolumn{4}{|c|}{ Open } \\
\hline & 2003 & 2005 & 2007 & 2012 & 2003 & 2005 & 2007 & 2012 \\
\hline 2 & 2 & 3 & 2 & 2 & 1 & 3 & 2 & 3 \\
\hline 4 & 1 & 7 & 3 & 1 & 3 & 7 & 2 & 9 \\
\hline 7 & 2 & 3 & 0 & 0 & 0 & 3 & 0 & 7 \\
\hline 10 & 13 & 16 & 10 & 8 & 4 & 6 & 2 & 4 \\
\hline 12 & 1 & 4 & 2 & 0 & 0 & 4 & 1 & 3 \\
\hline mean & 4 & 7 & 3 & 2 & 2 & 5 & 1 & 5 \\
\hline
\end{tabular}

\begin{tabular}{|c|c|c|c|c|c|c|c|c|}
\hline \multirow[b]{3}{*}{ Site } & \multicolumn{8}{|c|}{ Crushed \& Seeded } \\
\hline & \multicolumn{4}{|c|}{ Closed } & \multicolumn{4}{|c|}{ Open } \\
\hline & 2003 & 2005 & 2007 & 2012 & 2003 & 2005 & 2007 & 2012 \\
\hline 1 & 1 & 3 & 1 & 1 & 4 & 1 & 1 & 2 \\
\hline 5 & 4 & 12 & 2 & 4 & 0 & 6 & 2 & 3 \\
\hline 9 & 2 & 2 & 1 & 1 & 1 & 7 & 0 & 3 \\
\hline 14 & 1 & 1 & 0 & 0 & 1 & 3 & 3 & 0 \\
\hline 15 & 0 & 0 & 1 & 1 & 1 & 0 & 1 & 0 \\
\hline mean & 2 & 4 & 1 & 1 & 1 & 3 & 1 & 2 \\
\hline
\end{tabular}


Table A.7. Bare ground (exposed soil) percent cover estimates by treatment, $2003-2012$.

\begin{tabular}{r|rrrrrrrr} 
& \multicolumn{9}{|c}{ Closed } & \multicolumn{7}{c}{ Control } \\
\cline { 2 - 10 } \multicolumn{1}{r|}{ Site } & 2003 & 2005 & 2007 & 2012 & 2003 & 2005 & 2007 & 2012 \\
\hline 3 & 16 & 9 & 5 & 6 & 13 & 18 & 19 & 17 \\
6 & 20 & 25 & 15 & 19 & 21 & 19 & 20 & 20 \\
8 & 27 & 16 & 13 & 17 & 21 & 27 & 19 & 34 \\
11 & 13 & 8 & 4 & 13 & 25 & 18 & 21 & 21 \\
13 & 27 & 19 & 5 & 15 & 19 & 14 & 15 & 25 \\
\hline \multirow{2}{*}{ mean } & & & & & & & & \\
& $\mathbf{2 1}$ & $\mathbf{1 5}$ & $\mathbf{8}$ & $\mathbf{1 4}$ & $\mathbf{2 0}$ & $\mathbf{1 9}$ & $\mathbf{1 9}$ & $\mathbf{2 3}$
\end{tabular}

\begin{tabular}{r|rrrrrrrr} 
& \multicolumn{7}{c}{ Closed } & \multicolumn{7}{c}{ Crushed Only } \\
\cline { 2 - 9 } Site & 2003 & 2005 & 2007 & 2012 & 2003 & 2005 & 2007 & 2012 \\
\hline 2 & 20 & 22 & 2 & 0 & 24 & 18 & 6 & 10 \\
4 & 13 & 10 & 6 & 6 & 20 & 11 & 12 & 9 \\
7 & 19 & 10 & 12 & 16 & 22 & 18 & 12 & 12 \\
10 & 16 & 17 & 4 & 17 & 20 & 19 & 14 & 13 \\
12 & 18 & 10 & 12 & 16 & 18 & 14 & 13 & 13 \\
\hline & & & & & & & & \\
mean & 17 & 14 & $\mathbf{7}$ & $\mathbf{1 1}$ & $\mathbf{2 1}$ & $\mathbf{1 6}$ & $\mathbf{1 2}$ & $\mathbf{1 1}$
\end{tabular}

\begin{tabular}{r|rrrrrrrr} 
& \multicolumn{7}{c}{ Closed } & \multicolumn{7}{c}{ Crushed \& Seeded } \\
\cline { 2 - 10 } Site & 2003 & 2005 & 2007 & 2012 & 2003 & 2005 & 2007 & 2012 \\
\hline 1 & 22 & 13 & 3 & 3 & 11 & 14 & 10 & 11 \\
5 & 10 & 13 & 6 & 6 & 26 & 22 & 10 & 10 \\
9 & 14 & 20 & 3 & 17 & 19 & 17 & 6 & 13 \\
14 & 17 & 11 & 2 & 10 & 18 & 19 & 11 & 8 \\
15 & 10 & 9 & 8 & 12 & 26 & 13 & 4 & 21 \\
\hline & 15 & 13 & 4 & 10 & 20 & 17 & $\mathbf{8}$ & 13
\end{tabular}


Table A.8. Visible biological crust percent cover estimates by treatment, 2003 - 2012.

\begin{tabular}{|c|c|c|c|c|c|c|c|c|}
\hline \multirow[b]{3}{*}{ Site } & \multicolumn{8}{|c|}{ Control } \\
\hline & \multicolumn{4}{|c|}{ Closed } & \multicolumn{4}{|c|}{ Open } \\
\hline & 2003 & 2005 & 2007 & 2012 & 2003 & 2005 & 2007 & 2012 \\
\hline 3 & 1 & 0 & 13 & 16 & 1 & 1 & 5 & 7 \\
\hline 6 & 1 & 0 & 7 & 7 & 3 & 0 & 5 & 3 \\
\hline 8 & 1 & 0 & 4 & 8 & 0 & 0 & 1 & 0 \\
\hline 11 & 2 & 0 & 10 & 4 & 3 & 1 & 9 & 1 \\
\hline 13 & 0 & 5 & 16 & 11 & 3 & 1 & 6 & 4 \\
\hline mean & 1 & 1 & 10 & 9 & 2 & 1 & 5 & 3 \\
\hline
\end{tabular}

\begin{tabular}{|c|c|c|c|c|c|c|c|c|}
\hline \multirow[b]{3}{*}{ Site } & \multicolumn{8}{|c|}{ Crushed Only } \\
\hline & \multicolumn{4}{|c|}{ Closed } & \multicolumn{4}{|c|}{ Open } \\
\hline & 2003 & 2005 & 2007 & 2012 & 2003 & 2005 & 2007 & 2012 \\
\hline 2 & 2 & 0 & 3 & 10 & 3 & 0 & 2 & 6 \\
\hline 4 & 2 & 1 & 10 & 10 & 1 & 0 & 2 & 2 \\
\hline 7 & 2 & 0 & 3 & 6 & 4 & 1 & 3 & 1 \\
\hline 10 & 2 & 0 & 8 & 13 & 2 & 1 & 1 & 3 \\
\hline 12 & 4 & 2 & 2 & 1 & 6 & 1 & 1 & 0 \\
\hline mean & 3 & 1 & 5 & 8 & 3 & 1 & 2 & 2 \\
\hline
\end{tabular}

\begin{tabular}{|c|c|c|c|c|c|c|c|c|}
\hline \multirow[b]{3}{*}{ Site } & \multicolumn{8}{|c|}{ Crushed \& Seeded } \\
\hline & \multicolumn{4}{|c|}{ Closed } & \multicolumn{4}{|c|}{ Open } \\
\hline & 2003 & 2005 & 2007 & 2012 & 2003 & 2005 & 2007 & 2012 \\
\hline 1 & 3 & 1 & 4 & 12 & 0 & 1 & 0 & 3 \\
\hline 5 & 2 & 1 & 0 & 6 & 2 & 0 & 1 & 2 \\
\hline 9 & 1 & 0 & 3 & 3 & 0 & 0 & 0 & 0 \\
\hline 14 & 7 & 1 & 3 & 6 & 0 & 0 & 3 & 0 \\
\hline 15 & 2 & 1 & 2 & 7 & 1 & 0 & 2 & 1 \\
\hline mean & 3 & 1 & 3 & 7 & 1 & 0 & 1 & 1 \\
\hline
\end{tabular}

